\title{
Analisis Customer Relationship Management (CRM) terhadap Customer Relationship Quality (CRQ) dan Customer Lifetime Value (CLV) Rumah Zakat di Indonesia
}

\section{Andhi Irawan}

Pascasarjana Program Studi Manajemen, Universitas Lambung Mangkurat, Indonesia. E-mail: andhi irawan@yahoo.com

\section{ARTICLE INFO}

\author{
Kata Kunci: \\ Zakat; Amil Zakat \\ Institution; Customer \\ Relationship Management \\ (CRM); Customer \\ Relationship Quality \\ (CRQ); Customer Lifetime \\ $V$ alue (CLV).
}

\section{Cara Sitasi:}

Irawan, Andhi. "Analisis Customer Relationship Management (Crm) Terhadap Customer Relationship Quality (Crq) Dan Customer Lifetime Value (Clv) Rumah Zakat Di Indonesia." At-Taradhi: Jurnal Studi Ekonomi 10, no.1 (2019): 99-126

\section{ABSTRACT}

The background of this research is Islamic Economy development which is increasingly fast and the awareness zakat management which must be more professional and modern. Rumah Zakat as one of the largest private Zakat Institutions (LAZ) in Indonesia, has implemented Customer Relationship Management (CRM) tools to support the relationship of Rumah Zakat to the donors of Rumah Zakat by increasing Customer Lifetime Value (CLV) through the variables Customer Relationship Quality (CRQ). The results of this study indicate that the customer relationship management (CRM) process using customer relations tools can significantly influence Customer Relationships Quality (CRQ). Customer Relationships Quality (CRQ) can significantly Customer Lifetime Value (CLV). Customer Relationship Management (CRM) will not be able to directly influence a Customer Lifetime Value (CLV) significantly without Customer Relationship Quality (CRQ). Customer Relationship Management (CRM) will positively and significantly affect a Customer Lifetime Value (CLV) through Customer Relationships Quality(CRQ).

Latar belakang penelitian ini adalah pengembangan Ekonomi Islam yang semakin cepat dan kesadaran pengelolaan zakat yang harus lebih profesional dan modern. Rumah Zakat sebagai salah satu Lembaga Zakat swasta (LAZ) terbesar di Indonesia, telah menerapkan alat Customer Relationship Management (CRM) untuk mendukung hubungan Rumah Zakat dengan para donatur Rumah Zakat dengan meningkatkan Customer Lifetime Value (CLV) melalui variabel Pelanggan Kualitas Hubungan (CRQ). Hasil penelitian ini menunjukkan bahwa proses manajemen hubungan pelanggan (CRM) menggunakan alat hubungan pelanggan dapat secara signifikan mempengaruhi Customer Relationship Quality (CRQ). Customer Relationships Quality (CRQ) dapat secara signifikan Customer Lifetime Value (CLV). Customer Relationship Management (CRM) tidak akan dapat secara langsung mempengaruhi Customer Lifetime Value (CLV) secara signifikan tanpa Customer Relationship Quality (CRQ). Customer Relationship Management (CRM) akan secara positif dan signifikan mempengaruhi Customer Lifetime Value (CLV) melalui Customer Relationship Quality (CRQ). 


\section{Pendahuluan}

Sistem perkonomian syariah dinilai bisa meningkatkan keadilan dan kesejahteraan antar umat. mengatakan bahwa dipungutnya zakat dari mereka yang sudah mampu secara ekonomi adalah salah satunya agar harta tidak tertahan di kaum yang mampu saja. Tujuannya supaya pergerakan ekonomi jadi hidup. Jika zakat diberikan kepada mereka yang berhak, maka fakir miskin jadi punya daya beli. Jadi zakat juga bertujuan untuk mengembangkan ekonomi dan meningkatkan kesejahteraan.

Zakat adalah rukun pokok yang merupakan kewajiban bagi seluruh umat muslim yang berharta yang cukup. Zakat adalah bagian dari harta seorang muslim yang harus diserahkan kepada orang yang berhak menerimanya yang disebut dengan mustahik. Perkembangan dari pelaksanaan ibadah zakat diharapkan dapat dikelola agar lebih produktif dan dimanfaatkan lebih luas sehingga zakat bukan hanya sebatas nilai zakat itu sendiri, tapi bisa dikembangkan ke semua sektor kehidupan untuk membangun kehidupan yang sejahtera sebagai bekal untuk kerjasama kebajikan agar bisa bermanfaat untuk berjuang dijalan Allah. Kesejahteraan masyarakat bisa meningkatkan dengan memaksimalkan sumber daya pembiayaan syariah seperti zakat dan wakaf.

Para pengelola zakat tersebut harus bekerja secara professional dan tidak cuma mengambil hak Amil begitu saja. Profesionalitas itu harus dibarengi dengan kinerja yang baik dari berbagai aspek manajemen yang transparan dan amanah. Lembaga Amal Zakat (LAZ) tidak hanya harus memperhatikan dalam aspek penggalangan dana zakat dan menciptakan program pengentasan kemiskinan yang berkualitas. Tetapi juga dalam aspek sosialisasi dan komunikasi antara LAZ dan muzakki sebagai donatur. Aspek sosialisasi dan komunikasi sebagai syiar manfaat zakat amat perlu digalakkan kepada publik. Masih jauhnya realisasi penghimpunan dengan potensi zakat dikarenakan masih banyak masyarakat Indonesia belum memahami perihal zakat.

Rumah Zakat sebagai salah satu dari 17 LAZ yang terdaftar secara nasional, tentu mengemban beban untuk bisa mengelola dan menyalurkan zakat yang merupakan kewajiban umat Islam di Indonesia. Rumah Zakat telah meraih penghargaan Top Brand dari Majalah Marketing dan Frontier Consulting Group. CEO Rumah Zakat menyampaikan, pada Majalah Marketing dan Frontier Consulting Group memberikan penghargaan Rumah Zakat sebagai Top Brand 2017 untuk kategori badan zakat dan amal.

Rumah Zakat telah menggunakan teknologi informasi dalam operasionalnya. Rumah Zakat menggunakan Aplikasi CORE Z sebagai aplikasi kantor untuk menunjang pelaksanaan Customer Relationship Management berbasis teknologi informasi. Sejalan dengan perkembangan Rumah Zakat yang cukup pesat, proses kerja manual dinilai tidak lagi efektif. setiap jaringan kantor bisa online, minimal dengan sambungan Internet. koordinasi dan pengontrolan kantor cabang bisa semakin intensif dan murah ${ }^{1}$ serta dapat menunjang pelayanan. Modernisasi sistem TI di Rumah Zakat sejatinya mulai dilakukan pada akhir 2005 yang ditandai dengan diperkenalkannya konsep "Transformation from Traditional to Professional Corporate" di lingkungan Rumah Zakat. Kemajuan teknologi digunakan Rumah Zakat untuk meningkatkan hubungan pelanggan antara Muzakki dengan Lembaga Amal Zakat secara umumnya. Harapannya Keberhasilan Rumah Zakat dalam pengelolaan zakat berbasis pemasaran modern bisa juga sebagai pemicu pengembangan Badan Amil Zakat sebagai lembaga zakat milik pemerintah.

Perkembangan ini merupakan penerapan strategi pemasaran dalam pelaksanaan kewajiban umat Islam untuk meningkatkan ketaatan umat Islam dengan memberi kemudahan memenuhi salah satu rukun Islam yaitu membayar Zakat, Infaq dan Shadaqah. Salah satu Strategi pemasaran yang diterapkan di Rumah Zakat adalah Customer Relationship Management. Customer Relationship

\footnotetext{
1 “Agar Lebih Amanah Dalam Mengelola Dana Umat," SWA.Co.Id (blog), 12 Mei 2011,
} https://swa.co.id/swa/trends/technology/agar-lebih-amanah-dalam-mengelola-dana-umat. 
Management (CRM) didefinisikan sebagai pemahaman tentang apa yang dibutuhkan dan diinginkan seorang pelanggan dari sisi emosional serta memandang pelanggan sebagai asset jangka panjang yang akan memberikan kontribusi terus menerus selama kebutuhan mereka dipenuhi. ${ }^{2}$ Konsep CRM bertujuan untuk menciptakan keunggulan kompetitif secara terus menerus terhadap produk, jasa, merek dan perusahaan secara relatif dibandingkan dengan yang dimiliki oleh perusahaan pesaingnya. Konsep ini banyak digunakan sebagai salah satu strategi pemasaran setelah tahun 2000 dimana perkembangan ilmu pemasaran mengalami perubahan mendasar dari transaksional menjadi pemasaran berbasis hubungan.

Penggunaan media sosial sebagai saluran untuk keterlibatan pelanggan menimbulkan tantangan menarik bagi pendekatan manajemen hubungan pelanggan tradisional (CRM). Strategi CRM, yang dimungkinkan oleh proses dan teknologi, dirancang untuk mengelola hubungan pelanggan sebagai alat untuk menghasilkan nilai terbesar dari pelanggan selama masa hubungan antara Rumah Zakat dan Muzakkinya. CRM yang digunakan adalah CRM yang berintegrasi dengan teknologi informasi dan media sosial.

Penggunaan CRM bertujuan untuk meningkatkan nilai pelanggan seumur hidup (Customer Lifetime Value). Customer Lifetime Value (CLV) merupakan variabel dependen dari CRM. Penguatan hubungan pelanggan yang berkualitas berasal dari penelitian Penelitian Shwu-Ing Wu berfokus pada Relationship Quality dengan indikator Satisfaction, Trust dan Commitment. Tiga indikator tersebut merupakan faktor yang mempengaruhi loyalitas muzakki terhadap Rumah Zakat. RQ berfokus pada hubungan pelanggan dan perusahaan, kemudian ${ }^{3}$ mengembangkan indicator Customer Relationship Quality dengan menambahkan indikator Service, Solution dan Experience sebagai indikator yang berfokus pada peningkatan kualitas proses dan perbaikan terus-menerus.

Customer Relationship Quality (CRQ) merupakan metode spesifik dari suara pelanggan untuk mengerti dan mengelola kualitas hubungan jangka panjang pelanggan, untuk meningkatkan penjualan, serta efektivitas manajemen akun. CRQ dibangun berasal dari kombinasi kepercayaan (trust) antara pelanggan dengan penyalur, dan komitmen bersama antara kedua belah pihak untuk membangun hubungan kerjasama. Ketiga elemen kepercayaan, komitmen dan kepuasan menentukan kualitas hubungan bisnis yang dikendalikan dari presepsi dari solusi dan pengalaman, yang tergantung pada kualitas layanan yang diberikan oleh perusahaan. ${ }^{4}$

Penelitian Shwu-Ing Wu berfokus pada Relationship Quality dengan indikator Satisfaction, Trust dan Commitment. Tiga indikator tersebut merupakan faktor yang mempengaruhi loyalitas muzakki terhadap Rumah Zakat. RQ berfokus pada hubungan pelanggan dan perusahaan, kemudian Peter Lavers mengembangkan indikator Customer Relationship Quality dengan menambahkan indikator Service, Solution dan Experience sebagai indikator yang berfokus pada peningkatan kualitas proses dan perbaikan terus-menerus.

CRQ menjadi variabel intervening antara CRM dan Customer Lifetime Value (CLV), sehingga dalam penelitian ini CRM sebagai variabel eksogen dicoba untuk diintervensi variabel CRQ sehingga tidak langsung mempengaruhi variabel CLV sebagai variabel endogen. CRQ digunakan sebagai alat pengukur kualitas hubungan Rumah Zakat terhadap muzakkinya.

\footnotetext{
2 James G Barnes, Secrets of customer relationship management = Rahasia manajemen hubungan pelanggan (Yogyakarta: Andi, 2003).

3 Peter Levers, “The Value of Trust," Customer Attuned (blog), 19 Januari 2016, http://customerattuned.com/blog/the-value-of-trust/.

${ }^{4}$ Peter Levers.
} 
CLV adalah laba bersih yang diperoleh pelanggan tertentu selama seumur hidup. ${ }^{5}$ Penelitian Wu Shwu Ing membuktikan CRM berpengaruh positif terhadap Indikator CLV yaitu Usage Quantity, Loyalty, Word of Mouth dan Purchase Intention dengan Intervensi variable RQ. Menurut penelitian ${ }^{6}$ CRM berpengaruh positif terhadap RQ, dan RQ juga berpengaruh positif terhadap komponen CLV, dengan ditunjukkan dari nilai positif yang dihasilkan. CLV sebagai nilai keuntungan dari hubungan antar pelanggan menggunakan indikator loyalitas muzakki terhadap Rumah Zakat, dan indikator bentuk lain dari loyalitas berupa penggunaan ulang jasa Rumah Zakat, kesediaan untuk merekomendasikan jasa Rumah Zakat dan keinginan untuk menggunakan RZ kembali untuk membayar zakat. CLV menjadi tujuan akhir dari penggunaan akhir penggunaan CRM dan CRQ untuk mengukur nilai yang diperoleh muzakki dari pelaksanaan CRM dan CRQ, setelah menggunakan jasa Rumah Zakat untuk membayar zakat.

Pada saat ini banyak perusahaan menghabiskan investasi dalam Customer Relationship Management (CRM) sistem untuk menolong perusahaan mengumpulkan informasi berharga dari customer menyatakan karena pengusaha percaya bahwa hubungan antara perusahaan dan Pelanggannya langsung dan begitu dekat, efek positif dari CRM secara signifikan akan meningkatkan Kualitas Hubungan (RQ) antara industri dan pelanggan mereka, yang juga meningkatkan Nilai Seumur Hidup pelanggan atau Customer Lifetime V alue (CLV) (Wu Shwu-Ing, 2011). Penelitian ini juga bermaksud mengetahui hubungan dari CRM dengan CLV serta pengaruh yang diberikan CRQ ketika mengintervensi hubungan antara CRM dengan CLV.

Penelitian ini bertujuan ,menganalisis pengaruh CRM terhadap CLV, CRM terhadap CRQ, menganalisis pengaruh CRQ terhadap CLV, serta untuk menganalisis pengaruh intervensi CRQ antara CRM terhadap CLV. Manfaat yang diharapkan adalah sebagai masukan bagi perusahaan dalam mengelola penjualan, memanfaatkan CRM, mengefektifkan CRQ kegiatan dan aktivitas Rumah Zakat dalam rangka meningkatkan CLV Pelanggan.

Penelitian ini dilakukan dengan pendekatan Structural Equation Modeling (SEM). SEM dipilih karena memiliki fleksibilitas lebih tinggi bagi peneliti untuk menghubungkan antara teori dan data. Selain itu dalam ilmu ilmu sosial banyak variabel yang bersifat laten, seperti motivasi seseorang, komitmen, kesetiaan pelanggan, dan lainnya. Variabel - variabel tersebut baru bisa diukur dengan sejumlah indikator (variabel manifes), dan hubungan diantara keduanya, serta antar variabel laten memunculkan model yang membutuhkan alat analisis lanjutan. Model ini akan dianalisis dengan menggunakan Aplikasi IBM AMOS. Sehingga hasil dari penelitian ini dapat membantu pihak manajemen Rumah Zakat mengetahui faktor - faktor yang mempengaruhi CRQ dan CLV dari implementasi CRM.

\section{Landasan Teori}

\subsection{Zakat}

Agama Islam memiliki tuntunan harus mengeluarkan Zakat. Zakat merupakan harta yang wajib dikeluarkan bila memenuhi syarat tertentu, pada orang ditentukan, yaitu 8 (delapan) golongan yang punya hak menerima seperti tertulis dalam Al-Qur'an surat At-Taubah ayat ke 60 :

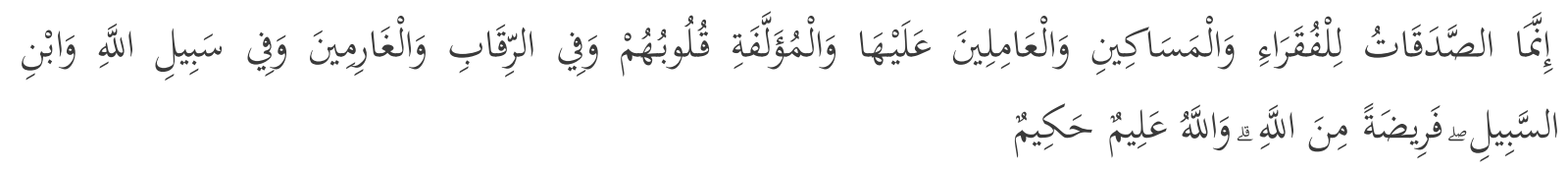

\footnotetext{
${ }^{5}$ Dommy Dyotama Satria, "Analisis Hubungan Antara Customer Relationship Management (Crm), Relationship Quality (Rq), Dan Customer Lifetime Value (Clv) (Studi Kasus: Hotel Grand Legi Mataram),” 2013.

${ }^{6}$ Satria.
} 
Artinya : "Sesunggubnya zakat-zakat itu, hanyalah untuk orang-orang fakir, orang-orang miskin, penguruspengurus zakat, para muallaf yang dibujuk. hatinya, untuk budak, orang-orang yang berbutang, untuk. jalan Allah dan untuk. mereka yuang sedang dalam perjalanan, sebagai suatu ketetapan yang diwajibkan Allah, dan Allab Maha Mengetahui lagi Maha Bijaksana."

Zakat dalam bahasa Arab punya berbagai makna yaitu : Pertama, zakat maknanya At-Thohuru, artinya mensucikan atau membersihkan. Makna ini menyatakan bahwa orang yang membayar zakat karena Allah, bukan karena pujian manusia, maka Allah akan mensucikan dan membersihkan jiwa dan harta. Firman Allah SWT didalam surat At-Taubah ayat 103:

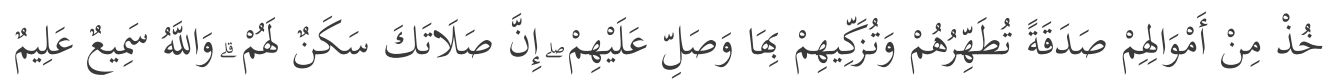

Artinya: "Ambillah zakat dari sebagian harta mereka, dengan zakat itu kamu membersibkan dan mensucikan mereka dan mendoalah untuk mereka. Sesunggubnya doa kamu itu ketenteraman jiwwa bagi mereka. Dan Allah Maha Mendengar lagi Maha Mengetabui”.

Kedua, zakat dengan makna Al-Barakatu, artinya berkah. Harta orang yang berzakat akan dilimpahkan keberkahan dari Allah SWT. Keberkahan hidup, jadi dampak keberkahan harta. Harta yang digunakan menjadi harta yang bersih dan suci, karena telah dibersihkan dari kotoran dengan melaksanakan zakat yang zakat itu sendiri berfungsi untuk mensucikan dan membersihkan harta.

Ketiga, zakat dengan makna An-Numuw, yang artinya berkembang dan tumbuh. Makna ini artinya bahwa orang yang berzakat, hartanya (dengan izin Allah) akan selalu terus berkembang dan tumbuh. Hal ini disebabkan oleh keberkahan harta dan kesucian telah tunai kewajiban zakat. Menurut ilmu Allah Maha Pemberi rizki, harta kita tidak berkurang dengan zakat, malah harta kita bertambah dengan berlipat ganda. Allah SWT berfirman dalam surat Ar-Rum ayat 39:

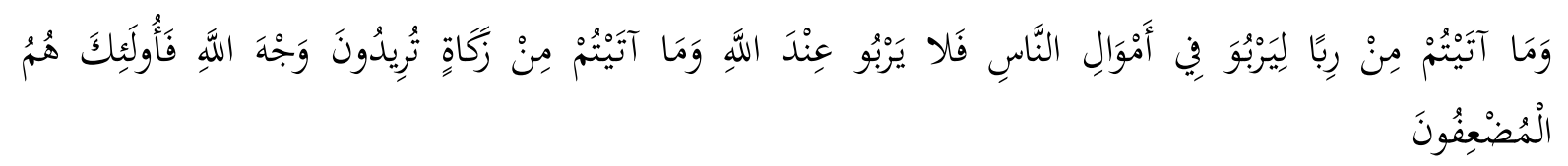

Artinya: "Dan sesuatu riba yang kamu berikan agar dia bertambah pada harta manusia, maka riba itu tidak menambah pada sisi Allah. Dan apa yang kamu berikan berupa zakat yang kamu maksudkan untuk mencapai keridhaan Allah, maka itulah orang-orang yang melipat gandakan."

Ayat ini Allah berfirman tentang firman tentang riba kemudian tentang zakat. Ayat ini Allah Tuhan Maha Pemberi Rizki menyatakan zakat dapat melipat gandakan harta dengan menunaikan zakat.

Keempat, zakat dengan makna As-Sholahu artinya keberesan, yaitu bahwa orang yang berzakat, hartanya selalu beres dan jauh dari semua masalah. Orang yang selalu ditimpa musibah atau masalah, bisa akibat karena mereka melalaikan zakat.

\subsection{Manajemen Zakat}

Pengelolaan zakat merupakan kegiatan pengelolaan, pendistribusian dan pengawasan terhadap zakat serta melakukan pendayagunan zakat. Zakat adalah harta yang wajib dibayarkan oleh umat muslim atau badan hukum yang di miliki oleh muslim berdasarkan ketentuan agama diserahkan pada yang berhak.

Tujuan pendirian lembaga pengelolaan zakat adalah 1. Peningkatan fungsi dan peranan pranata keagamaan untuk upaya mewujudkan keadilan sosial dan kesejahteraan masyarakat. 2..Peningkatan hasil guna dan daya guna zakat.3. peningkatkan pelayanan dalam menunaikan zakat, sesuai dengan tuntutan zaman. 
Lembaga Amil Zakat (LAZ) dan Badan Amil Zakat (BAZ) di Indonesia merupakan 2 (dua) lembaga yang bertugas untuk mengelola, mendayagunakan dan mendistribusikan,zakat. Badan dan Lembaga Zakat ini didasarkan Hak Amil yang tertulis dalam PP No. 14 Tahun 2014 sebagai bagian tertentu dari zakat yang dapat digunakan untuk biaya operasional dalam pengelolaan zakat sesuai syariat.

Pemerintah mendirikan Badan Amil Zakat adalah lembaga pengelola zakat yang yang didirikan atas usul Kementrian Agama dan telah disetujui oleh Presiden. Ibu kota negara Jakarta adalah kedudukan Kantor Pusat BAZ. Anggota BAZNAS terdiri dari 11 orang anggota yakni delapan orang dari unsur masyarakat (tokoh masyarakat Islam, tenaga profesional dan Ulama) dan tiga orang dari unsur pemerintah (ditunjuk dari kementerian yang berkaitan dengan pengelolaan zakat).

LAZ merupakan "lembaga pengelola zakat yang dibentuk oleh diluar pemerintah atau swasta". LAZ adalah intitusi pengelolaan zakat yang sepenuhnya dibentuk masyarakat dan prakarsa masyarakat bergerak dibidang da'wah, sosial, pendidikan dan kebaikan umat Islam. LAZ ini dibina, dilindungi dan dikukuhkan pemerintah, LAZ melapor pada pemerintah sesuai dengan tingkatan.. Pengukuhan LAZ dilakukan oleh pemerintah dari usulan LAZ yang memenuhi persyaratan.

Pengumpulan, pendistribusian, dan pengelolaan zakat telah ada lebih dahulu dimasyarakat, sebelum berlakunya undang-undang pengelolaan zakat. Fungsi ini dikelola masyarakat sendiri, baik secara kelompok kelembagaan atau perorangan. Berlaku undang-undang ini, menjadi proses formalisasi lembaga zakat yang sudah ada. Istilah formal lembaga jadi disamakan menjadi Lembaga Amil Zakat (LAZ) sebagai lembaga formal yang berfungsi mengelola zakat, untuk lembaga yang sebelumnya sudah ada di tengah-tengah masyarakat secara informal, harus melalui proses formal administratif, kemudian diresmikan oleh pemerintah sebagai bentuk pengakuan secara formal. Berdasarkan Undang-Undang Nomor 38 Tahun 1999, tidak semua kelembagaan maupun perorangan melakukan kegiatan mengumpulkan, mendistribusikan dan mengelola zakat dinamakan Lembaga Amil Zakat..

\subsection{Customer Relationship Management}

Asal-usul pendekatan berbasis hubungan dengan manajemen perusahaan muncul dari kalangan akademisi dan praktisi di bidang strategi, pemasaran dan manajemen rantai pasokan mulai mendapatkan pemahaman tentang aktivitas pemasaran sebagai pertukaran antara penjual dan pembeli - sehingga membentuk dasar untuk konseptualisasi pemasaran hubungan selanjutnya. Pertanyaannya adalah untuk memahami bagaimana hubungan berkembang dan berubah selama periode waktu tertentu. Kemungkinan penggambaran fase dalam suatu hubungan membuat perlu mendesain hubungan pemasaran secara eksplisit. Konseptualisasi ini pertama kali muncul pada awal tahun 1980an di bidang penelitian pemasaran jasa. Konsep Relationship Marketing Konsep Relationship Marketing lahir di bidang pemasaran jasa dan pemasaran industry.Pada tahun 1992, Webster melaporkan bahwa telah terjadi pergeseran paradigma dari fokus 'transaksi' ke fokus 'hubungan'. Dari fokus yang sempit pada pemasaran pada volume dan keuntungan-maksimal, telah menjadi berorientasi yang luas dengan penekanan pada pembentukan hubungan pelanggan jangka panjang dan mengelola aliansi strategis dengan pelanggan secara langsung dan melalui rekan rantai pasokan lainnya

Hubungan dengan pelanggan merupakan hal yang fundamental bagi sukses jangka panjang sebuah perusahaan. Keberadaan hubungan pelanggan yang kuat dan sejati akan menciptakan loyalitas. Konsep hubungan pelanggan tidak hanya terbatas pada situasi ketika perusahaan bertemu dengan pelanggan baik langsung maupun melalui sarana teknologi namun lebih dari itu yaitu suatu hubungan emosional. 
Penelitian ini menggunakan perspektif pelanggan untuk menyelidiki apakah pelanggan mengetahui praktik CRM yang diterapkan oleh Rumah Zakat atau tidak. Hal ini membutuhkan evaluasi tingkat kesadaran konsumen akan adanya tindakan CRM oleh pihak Rumah Zakat. menemukan bahwa kebutuhan pelanggan akan tindakan CRM mencakup saluran layanan yang lebih beragam, kepercayaan yang lebih besar pada layanan hotel, biaya layanan rendah, akses cepat ke layanan, jam kerja yang diperpanjang, akses mudah ke layanan, privasi perlindungan, dan layanan yang disesuaikan. Studi ini memodifikasi variabel di atas agar sesuai dengan Lembaga Amal Zakat, dan menggunakan item ini sebagai variabel CRM untuk mengevaluasi kesadaran pelanggan terhadap praktik CRM di Rumah Zakat. Indikator CRM yang digunakan adalah :

1. Continuity Marketing merupakan program pemasaran untuk mempertahankan dan meningkatkan loyalitas pelanggan melalui pelayanan khusus yang bersifat jangka panjang, serta meningkatkan nilai dengan cara mempelajari karakteristik dari pelanggan. Program continuity marketing dapat berbentuk program kartu keanggotaan dimana pelanggan diberi penghargaan berupa layanan khusus secara individu, diskon dan poin untuk upgrades, serta program penjualan silang (cross selling).

2. One to One Marketing merupakan program yang dilakukan secara individual yang ditujukan untuk memenuhi kepuasan atas kebutuhan yang unik dari pelanggan. Program one to one marketing menggunakan informasi pelanggan yang berasal dari informasi online dan database, yang dilanjutkan dengan interaksi secara individu dengan pelanggan untuk memenuhi kebutuhan unik dari pelanggan. Informasi pelanggan secara individu digunakan untuk membangun pemasaran interaktif dan program paska pemasaran dalam mengembangkan pelanggan.

3. Partnering Program merupakan hubungan kerjasama antara pemasar dengan perusahaan lain untuk melayani kebutuhan pelanggan akhir.

Istilah lain dari uraian diatas perusahaan akan berusaha membantu pelanggan untuk mendapatkan apa yang diinginkan dengan cara bekerjasama dengan perusahaan-perusahaan lain diluar sana.

Indikator berbasis tehnologi CRM menurut BM Ghodeswar yang digunakan dalam penelitian ini adalah :

1. Customer Database, Perusahaan yang memiliki sistem informasi yang baik dapat membantu aliran informasi dan koleksi informasi yang sistematis dan mudah dievaluasi dan dikomparasi dalam deret waktu tertentu yang memudahkan memahami pelanggan dan bias dengan akurat mengantisipasi perilaku pelanggan.

2. Electronic Point of Sales(EPOS), EPOS merupakan penggunaan alat elektronik dalam layanan pelanggan yang digunakan untuk memenuhi kebutuhan pelanggan dalam menerima informasi.

3. Sales Force Automation, Sistem otomasi sales memudahkan sales untuk mengotomasi dan mengoptimalkan proses penjualan serta mempersingkat waktu dan meningkatkan produktivitas sales.

4. Customer Service Helpdesk, Sistem memudahkan perusahaan atau lembaga untuk mengotomasi proses layanan untuk mencari solusi pada pelanggan untuk menjalankan layanan berkualitas tinggi..

5. Call Centres menolong untuk mengotomasi operasi untuk menerima panggilan telepon dari pelanggan antara perusahaan dan pelanggan dengan system yang memadukan antara jawaban dari system dan petugas operator telepon

6. System Integration, Pihak back office juga memerlukan aplikasi yang mengotomasi layanan support dalam operasionalisasi pekerjaan mereka, phak back office ini bias berupa bagian keuangan, kepegawaian, umum dan lain-lain. 
Indikator Berdasarkan ${ }^{7}$ yaitu Social Media juga ditambahkan dalam penelitian ini, untuk memenuhi perkembangan tehnologi informasi. Sosial Media adalah aplikasi pertemanan berbasis internet.

\subsection{Customer Relationship Quality}

Customer Relationship Quality (CRQ) merupakan metode spesifik dari suara pelanggan untuk mengerti dan mengelola kualitas hubungan jangka panjang pelanggan dan untuk meningkatkan penjualan dan efektivitas manajemen akun yang telah diterapkan dan diadopsi ke perusahaan blue chip di Apple, Atos, HSBC, Reed Elsavier, Santander dan Vitality Health. CRQ dibangun berasal dari kombinasi kepercayaan (trust) antara pelanggan dengan penyalur, dan komitmen bersama antara kedua belah pihak untuk membangun hubungan kerjasama. Ketiga elemen kepercayaan, komitmen dan kepuasan menentukan kualitas hubungan bisnis yang dikendalikan dari presepsi dari solusi dan pengalaman, yang tergantung pada kualitas layanan yang diberikan oleh perusahaan. ${ }^{8}$ CRQ adalah pengembangan Relationship Quality (RQ) dengan indikator Kepercayaan, Kepuasan Pelanggan dan Komitmen Pelanggan. Tiga Indikator tambahan dari Peter Laverz untuk Customer Relationship Quality adalah Service, Solution, Experience.

Manfaat yang diharapkan dari CRQ adalah, (1) Menjadi lebih customer centric/ orientasi pelanggan, (2) Memahami, mengelola dan meningkatkan kualitas hubungan pelanggan Anda, (3) Membuat penjualan Anda, distribusi dan saluran komunikasi (fisik dan digital) bekerja lebih cerdas, serta (4) Menarik, mengelola, memotivasi, mengembangkan dan menjaga karyawan Perusahaan. $^{9}$

Relationship Quality (RQ) adalah indeks penting untuk mengevaluasi kekuatan hubungan antara pemasok dan pelanggan. Banyak peneliti sepakat bahwa kepercayaan pelanggan, kepuasan dan komitmen, merupakan faktor kunci dalam mengevaluasi RQ. Sebagai contoh, mengemukakan bahwa kepuasan dan kepercayaan merupakan aspek kunci RQ; kepercayaan dan komitmen merupakan faktor kunci dalam mengevaluasi RQ. Menyimpulkan bahwa RQ dibentuk oleh kepuasan, kepercayaan dan komitmen. Dengan demikian, penelitian ini mengintegrasikan tiga item di atas untuk mengukur RQ. Bagian berikut menjelaskan faktor-faktor ini secara lebih rinci.

"Kepercayaan" berarti bahwa pelanggan percaya bahwa tenaga penjualan akan memberi mereka keuntungan dan layanan jangka panjang. kepercayaan adalah reputasi dan tingkat perhatian yang ditunjukkan oleh pihak yang berlawanan seperti yang diakui oleh pengambil keputusan pada sasaran yang dapat dipercaya, dan mencakup reputasi objektif dan perawatan psikologis. kepercayaan adalah kepercayaan pelanggan terhadap kualitas dan keandalan layanan yang diberikan oleh organisasi.

Kepercayaan adalah tingkat kepercayaan dan kemauan dalam pikiran konsumen. Artinya, kepercayaan konsumen bergantung pada kepercayaan dan kemauan untuk berurusan dengan perusahaan, dan kemauan seperti itu berasal dari keandalan, integritas dan kejujuran perusahaan.

Pelanggan "kepuasan" berarti kepuasan pelanggan selama atau setelah pembelian produk atau layanan, interaksi dengan petugas servis, dan keseluruhan pengalaman yang diberikan oleh perusahaan dibandingkan dengan perusahaan lain. Kepuasan adalah proses pengakuan dan evaluasi dimana pelanggan membandingkan pengalaman aktual mereka dengan harapan mereka sebelumnya. Jika produk memenuhi atau melampaui ekspektasi ini, pelanggan merasa puas. Kepuasan pelanggan berarti tingkat suka atau tidak suka setelah konsumsi, yang merupakan sikap

\footnotetext{
${ }^{7}$ Carolyn Heller Baird dan Gautam Parasnis, "From Social Media to Social Customer Relationship Management," Strategy \& Leadership, 6 September 2011, https://doi.org/10.1108/10878571111161507.

8 Peter Levers, "The Value of Trust."

${ }^{9}$ Peter Levers.
} 
yang didasarkan sepenuhnya pada pengalaman. Dengan demikian, kepuasan pelanggan secara keseluruhan merupakan penentu utama RQ.

"Komitmen" pelanggan sangat penting untuk menjaga hubungan dengan pihak lain. Komitmen terhadap hubungan kedua mitra merupakan faktor kunci bagi RQ yang sukses dalam jangka panjang, dan membantu meningkatkan manfaat jangka panjang. Komitmen untuk menyadarkan saat mitra ingin melanjutkan dan memperkuat hubungan tersebut. Komitmen mencakup keinginan untuk mengembangkan hubungan yang stabil, kemauan untuk melakukan pengorbanan jangka pendek untuk hubungan jangka panjang, dan memiliki kepercayaan terhadap stabilitas hubungan. Untuk memastikan validitas konten timbangan, item pengukuran dipilih dan dimodifikasi dari studi sebelumnya. Langkah-langkah untuk Kepercayaan, Kepuasan Pelanggan dan Komitmen Pelanggan didasarkan pada tiga Indikator tambahan dari Peter Laver untuk Customer Relationship Quality adalah Service, Solution, Experience.

Hermawan Kertajaya menyatakan Service merupakan sebuah paradigma dari orang dalam sebuah perusahaan, tidak peduli apakah sebuah perusahaan yang menhasilkan product atau service untuk selalu memberikan best value pada pelanggannya. Ahman Sutardi \& Endang Budiasih menyatakan service adalah setiap kegiatan untuk atau bertujuan untuk memberikan kepuasan melalui pelayanan yang diberikan seseorang secara memuaskan. Service ialah "value enhancer" produk dan perusahaan anda. Service merupakan sebuah rangkaian proses, dan sebagai proses ia berkaitan dengan input - output.

Meskipun service sering kali memasukkan komponen tangibles yang penting, komponen ini bersama - sama dengan personel yang ahli menjadi kombinasi yang dominan dalam rangkaian value creation untuk penciptaan kinerja jasa. Mohd Rozani Pawan Chek menyatakan Service adalah merupakan gabungan dari selling (menjual), emphasis (menekankan), return (timbal balik), Visit (mengunjungi), Increase (menambah atau meningkatkan), commitment (mengikatkan diri), dan earn (penghasilan). Laurensius Manurung menyatakan Service merupakan aktivitas perusahaan dalam memberikan layanan pelanggan meliputi penanganan pelanggan dan keluhan pelanggan. Holy Icun Y \& Martinus Getty menyatakan Service merupakan komponen tambahan seperti garansi jasa, garansi spare part, asuransi, dll.

Definisi Solution diantaranya 1. campuran homogen dari dua atau lebih zat. 2. sebuah pernyataan yang memecahkan masalah atau menjelaskan bagaimana memecahkan masalah secara kongkrit. 3 . sebuah metode untuk memecahkan suatu masalah.4. himpunan nilai yang memberikan pernyataan yang benar saat digantikan dengan sebuah persamaan.5. sukses memecahkan masalah. Jadi Solution merupakan suatu metode pemecahan masalah yang terjadi dalam layanan yang diberikan perusahaan ke pelanggan.

Experience berdefinisi 1. akumulasi pengetahuan atau keterampilan yang dihasilkan dari partisipasi langsung dalam kejadian atau aktivitas. 2. isi pengamatan langsung atau partisipasi dalam suatu peristiwa. 3. sebuah kejadian yang ditangkap secara utuh. 4. Uji coba, sebagai tes atau percobaan. 5. pergi atau hidup melalui.6. Memiliki pengetahuan langsung tentang keadaan, situasi, emosi, atau sensasi secara langsung. 7. melalui (kondisi mental atau fisik atau pengalaman). 8. mengalami sensasi emosional atau berada dalam keadaan tertentu pikiran. Definisi yang di ambil yaitu akumulasi pengetahuan atau keterampilan dari partisipasi langsung berupa melihat, mengamati, uji coba, merasakan, mengalami keadaan, situasi, emosi secara langsung dari kondisi fisik, mental atau pengalaman akan sesuatu.

\subsection{Customer Lifetime Value (CLV)}

Customer Lifetime Value (CLV) adalah laba bersih yang diperoleh dari pelanggan tertentu selama seumur hidup pelanggan itu, karena ia terus membeli produk dari perusahaan. Dengan demikian, CLV merupakan keuntungan yang dihasilkan oleh semua langkah-langkah yang diperlukan perusahaan untuk menjaga hubungan dengan pelanggan yang sama. Akan tetapi Blatterg dan 
Deighton menunjukkan bahwa tidak semua pelanggan sama, seperti persaingan di pasar menjadi lebih parah, mempertahankan pelanggan yang berharga menjadi lebih penting bagi perusahaan. ${ }^{10}$ Pepper dan Rogers menemukan bahwa pelanggan dengan RQ tinggi akan merekomendasikan produk dari mulut ke kerabat dan teman-teman . Pelanggan ini lebih bersedia untuk membeli dan juga memiliki kesetiaan yang lebih tinggi. Selain itu, pelanggan dengan loyalitas tinggi akan memberikan kontribusi untuk keuntungan perusahaan dalam jangka panjang dan meningkatkan penjualan dan keuntungan perusahaan.

Garbarino dan Johnson menemukan bahwa RQ mempengaruhi kesediaan pelanggan untuk tinggal atau pergi di masa depan. Selain itu mereka juga menemukan bahwa RQ antara pelanggan dan perusahaan merupakan faktor kunci dalam loyalitas pelanggan. Kumar dkk, berpikir bahwa RQ baik mengurangi konflik antara pelanggan dan perusahaan, meningkatkan loyalitas pelanggan terhadap perusahaan, meningkatkan kesediaan pelanggan untuk transaksi terus, dan meningkatkan jumlah pelanggan penggunaan. Leu dan Hsieh menemukan bahwa RQ memiliki pengaruh signifikan terhadap jumlah pelanggan, loyalitas, niat pembelian produk, dan word of mouth. Temuan ini menunjukkan bahwa semakin tinggi kepuasan pelanggan dengan RQ menciptakan pandangan positif dari pelanggan. Hal ini pada akhirnya akan meningkatkan keuntungan perusahaan dan meningkatkan CLV. ${ }^{11}$

Tujuan akhir dari CRM untuk perusahaan adalah untuk meningkatkan "Nilai Pelanggan Seumur Hidup." Oleh karena itu, efek CRM pada akhirnya meningkatkan CLV melalui RQ. Pelanggan dengan RQ tinggi akan merekomendasikan produk dari mulut ke mulut kepada saudara dan teman. Pelanggan ini lebih rela melakukan pembelian ulang dan juga memiliki loyalitas yang lebih tinggi. Apalagi, pelanggan dengan loyalitas tinggi akan memberikan kontribusi terhadap keuntungan perusahaan dalam jangka panjang dan meningkatkan penjualan dan keuntungan perusahaan.

Penelitian ini mengukur CLV dengan jumlah pemakaian (usage quantity), loyalitas (loyalty), kata dari mulut ke mulut (word of mouth), dan niat beli (purchase intention).

Mowen and Minor (2002:180) mengungkapkan Word of Mouth Communication mengacu pada pertukaran komentar, pemikiran, atau ide-ide di antara dua konsumen atau lebih, yang tak satupun merupakan sumber pemasaran. Informasi word of mouth tersebut langsung berasal dari orang lain yang menggambarkan secara pribadi pengalamannya sendiri, maka ini jauh lebih jelas bagi konsumen daripada informasi yang terdapat dalam iklan. Komunikasi mulut ke mulut dapat menstimulus atau merangsang konsumen dalam melakukan pembelian. Model Word of Mouth ada dua model Word of Mouth yaitu Organic Word of Mouth dan Amplifled Word of Mouth dalam (WOMMA, 2007) sebagai berikut: 1. Organic Word of Mouth Organic Word of Mouth adalah word of mouth yang terjadi secara alami, orang yang merasa puas pada sebuah produk akan membagi antusiasme mereka. 2. Amplified Word of Mouth Amplified Word of Mouth adalah word of mouth yang terjadi karena di desain oleh perusahaan.

Assael ${ }^{12}$ mendefinisikan loyalitas sebagai " a favorable attitude toward a brand resulting in consistent purchase of the brand over time." Literatur pemasaran menyatakan bahwa loyalitas dapat dipahami dari dua dimensi sebagai berikut. Loyalty is behavioral, artinya loyalitas dapat dipahami sebagai konsep yang menekankan pada runtutan pembelian, proporsi pembelian, probabilitas pembelian. Pemahaman ini sering disebut sebagai behavioral approach (pendekatan keperilakuan). 2. Loyalty as

\footnotetext{
${ }^{10}$ Satria, "Analisis Hubungan Antara Customer Relationship Management (Crm), Relationship Quality (Rq), Dan Customer Lifetime Value (Clv) (Studi Kasus."

${ }^{11}$ Satria.

12 H Assael, Consumer Behavior and Marketing Action. (Boston, Mass: Kent Publishing Company, 1987), 130.
} 
an attitude, artinya loyalitas dipahami sebagai komitmen psikologis pelanggan terhadap obyek tertentu. Pemahaman ini sering disebut sebagai attitudinal approach (pendekatan attitudinal).

Purchase Intention, atau minat beli menurut Assael ${ }^{13}$ merupakan "kecenderungan konsumen untuk membeli suatu merek atau mengambil tindakan yang berhubungan dengan pembelian diukur dengan tingkat kemungkinan konsumen melakukan pembelian". Minat beli sebagai kecenderungan konsumen untuk membeli suatu merek atau mengambil tindakan yang berhubungan dengan pembelian yang diukur dengan tingkat kemungkinan konsumen melakukan pembelian.

Pengertian minat beli adalah minat beli merupakan rencana konsumen untuk membeli produk tertentu serta berapa banyak unit produk yang dibutuhkan selama periode tertentu. minat beli merupakan pernyataan dari pikiran konsumen yang menunjukkan rencana pembelian produk dengan merk tertentu. Hal ini diperlukan pemasar untuk mengetahui minat beli konsumen terhadap produk. Para pemasar maupun ahli ekonomi menggunakan variabel minat untuk meramal perilaku konsumen di masa datang.

Kerangka Konsep dari Penelitian ini menggunakan variabel CRM, CRQ, dan CLV. Variabel Customer Relationship Management (CRM) ini secara operasional diukur dengan menggunakan 10 (sepuluh) indikator yang diadopsi dan disesuaikan dari ${ }^{14}$ yaitu: Continuity Marketing; One to One Marketing; Partnering Program, serta Customer Database, Electronic Point of Sales, Sales force Automotion, Customer Service Helpdesk, Call Centers, System Integration serta social media. Variabel CRQ menggunakan 6 (enam) indikator ${ }^{15}$ yaitu Service; Solution; Experience; Trust; Satisfaction; Comitment. Variabel CLV menggunakan 4 (empat) Indikator yaitu Usage Quantity, Loyalty, Word of Mouth, dan Purchase Intention.

\subsection{Hubungan Antar Variabel}

\subsubsection{Hubungan CRM dengan CLV}

CLV merupakan tujuan akhir dari pelaksanaan CRM. ${ }^{16}$ Berdasarkan uraian sebelumnya maka hipotesis yang diajukan adalah sebagai berikut :

H1 : Ada Pengaruh Positif dari hubungan CRM terhadap CLV

\subsubsection{Hubungan CRM dengan CRQ}

CRM diadopsi untuk meningkatkan hubungan dengan pelanggan. CRQ merupakan standarisasi pelaksanaan CRM dengan indikator Trust; Satisfaction; Comitment ${ }^{17}$, Service; Solution; Experience $^{18}$; yang dilaksanakan oleh perusahaan. Berdasarkan uraian sebelumnya maka hipotesis yang diajukan adalah sebagai berikut :

H2 : Ada Pengaruh Positif dari hubungan CRM terhadap CRQ

\subsubsection{Hubungan CRQ dengan CLV}

CRQ merupakan standarisasi pelaksanaan hubungan antara perusahaan dengan pelanggan sehingga pelaksanaan penguatan hubungan antara perusahaan dengan pelanggan untuk bisa

\footnotetext{
13 Assael, Consumer Behavior and Marketing Action.

14 Philip Kotler dan Kevin Lane Keller, Marketing Management, 2017.

15 Peter Levers, "The Value of Trust."

16 Philip Kotler dkk., Marketing management (Paris: Pearson Education France, 2009).

17 satria, "Analisis Hubungan Antara Customer Relationship Management (Crm), Relationship Quality (Rq), Dan Customer Lifetime Value (Clv) (Studi Kasus.”

18 Peter Levers, "The Value of Trust."
} 
memuaskan kebutuhan pelanggan terhadap produk yang dijual dan layanan yang diberikan kepada pelanggan. ${ }^{19}$ Berdasarkan uraian sebelumnya maka hipotesis yang diajukan adalah sebagai berikut :

\section{H3 : Ada Pengaruh Positif dari hubungan CRQ terhadap CLV}

\subsubsection{Hubungan CRM dengan CLV dengan intervensi CRQ}

CRM diadopsi untuk meningkatkan hubungan dengan pelanggan. CRQ merupakan standarisasi pelaksanaan CRM dengan indikator Service; Solution; Experience; Trust; Satisfaction; Comitment yang dilaksanakan oleh perusahaan, sebagai fokus titik sentuh (touch point) untuk memenuhi CLV yang merupakan bentuk lain dari loyalitas pelanggan. ${ }^{20}$ Berdasarkan uraian sebelumnya maka hipotesis yang diajukan adalah :

H4 : Ada Pengaruh Positif dari hubungan CRM terhadap CLV dengan Intervensi CRQ

\subsection{Model Hubungan antara CRM, CRQ, dan CLV}

\section{Gambar 1. Model Diagram Alur Hubungan Kausalitas}

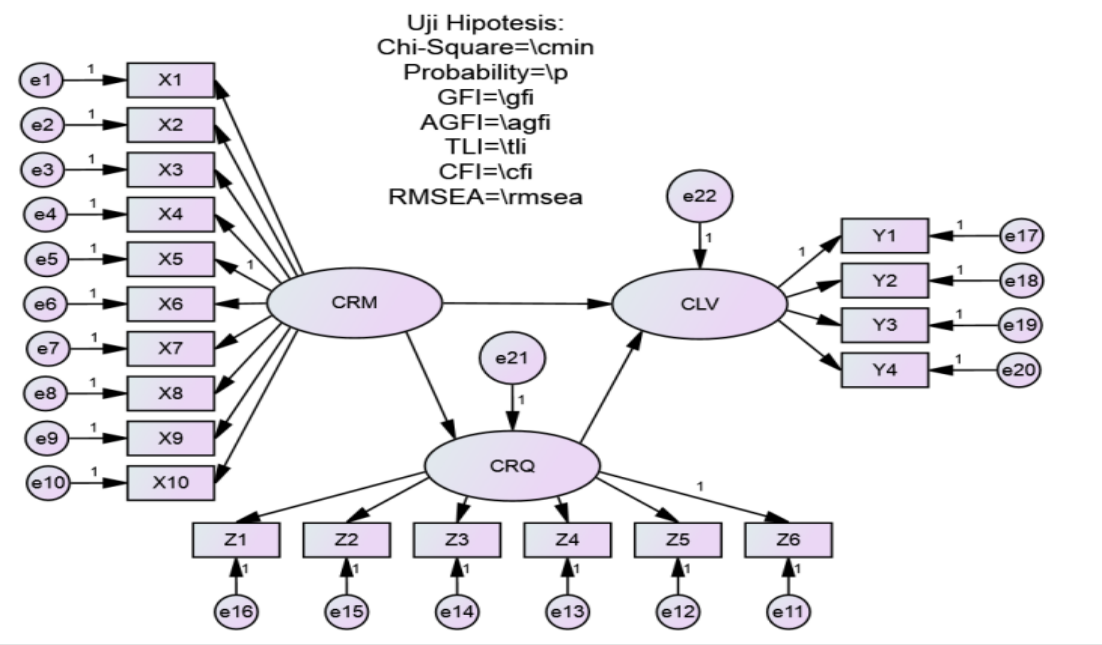

(sumber : Diolah Menggunakan SEM AMOS 2.4.)

Penentuan Variabel Eksogen dan Variabel Indogen dalam model penelitian ini dibagi sebagai berikut:

a. Customer Relationship Management (CRM) merupakan variabel Eksogen sedangkan Customer Relationship Quality (CRQ) sebagai variabel Endogen.

b. Customer Relationship Quality (CRQ) merupakan variabel Intervening sedangkan Customer Lifetime Value (CLV) sebagai variabel Endogen.

\section{Metode Penelitian}

Metode pengumpulan data digunakan agar dapat menghasilkan data yang akurat dan valid, desain instrumen penelitian dan desain dasar kuisioner yang akan digunakan untuk mengumpulkan data, serta alat analisis dan pengambilan keputusan atau implikasi manajerial berdasarkan data yang terkumpul. Sistematika yang disusun untuk penelitian berjalan konsisten sesuai dengan maksud dan tujuan dari penelitian.

\footnotetext{
${ }^{19}$ Peter Levers.

${ }^{20}$ Kotler dkk., Marketing management.
} 


\subsection{Desain dan Obyek Penelitian}

\section{Desain penelitian}

Penelitian ini bertipe desain penelitian kausalitas yaitu mengidentifikasi hubungan sebab akibat antar variabel, peneliti mencari model sesungguhnya dari fakta untuk membantu memahami dan memprediksi hubungan antar variabel yang kemudian dikembangkan dalam suatu bentuk model penelitian untuk menguji 4 (empat) hipotesis dari penelitian yang sudah ditentukan pada bab sebelumnya.

\section{Obyek penelitian}

Obyek penelitian ini adalah donatur Rumah Zakat di Indonesia, dikarenakan rumah zakat menerima juga menerima, infak, sedekah dan kurban.

\subsection{Jenis data dan Sumber Data}

Penelitian ini menggunakan data primer yaitu data yang langsung didapat dari obyek penelitian (Arikunto, 1996). Data diperoleh dengan penggunaan daftar pertanyaan (kuesioner) yang sudah dipersiapkan. Kuesioner dalam penelitian ini berisi tentang pernyataan bagaimana CRM berpengaruh terhadap CRQ dan terhadap CLV. Data primer dalam penelitian ini yaitu data berupa jawaban atau tanggapan atas pernyataan yang diperoleh secara langsung dari responden, yang ada di dalam kuesioner. Data sekunder juga diperlukan sebagai konfirmasi teori dan informasi yang bisa diperoleh dari studi kepustakaan (jurnal, data perusahaan, artikel, website $\mathrm{dsb}$ ) yang berhubungan dengan penelitian yang dilakukan.

\subsection{Populasi dan sampel}

\section{Populasi}

Populasi menurut Anderson merupakan kumpulan semua elemen yang memiliki satu atau beberapa atribut yang menjadi tujuan. Jadi populasi adalah jumlah keseluruhan objek penelitian. Populasi adalah wilayah generalisasi, terdiri dari kesimpulan dari obyek atau subyek yang mempunyai kualitas dan karakteristik yang menjadi ketetapan peneliti. Populasi yang dipilih dalam penelitian ini adalah donatur dari Rumah Zakat.

\section{Sampel}

Sampel adalah bagian dari populasi yang memiliki karakteristik yang dianggap bisa mewakili populasi yang dianggap relatif sama. Jumlah sampel memegang peranan penting dalam menginterpretasikan hasil, sesuai dengan alat analisis yang digunakan yaitu Structural Equation Modelling (SEM) maka jumlah sampel yang representatif dengan cara jumlah indikator dikali 5 sampai 10. Jumlah sampel untuk penelitian ini adalah :

Sampel min $=$ Jumlah indicator $\times 5$

$$
=20 \times 5
$$

$=100$ responden

Sampel maks $=$ Jumlah indicator $\mathrm{x} 10$

$$
=20 \times 100
$$

$=200$ responden

Jumlah sampel yang digunakan dalam penelitian ini sebanyak 201 responden. Terjadi kelebihan data yang masuk, dikarenakan responden yang telah menginput formulir kuesioner di google form, telah terinput jawaban dari 201 responden. Google form tidak memiliki sistem otomatis untuk menutup input respon dari responden kuesioner penelitian. Semakin besar jumlah sampel maka bias untuk menggenaralisir hasil penelitan semakin kecil, pengambilan sampel lebih 
bermanfaat, untuk antisipasi dari penghapusan data karena adanya data outlier dari perhitungan aplikasi SEM AMOS 2.4. Jumlah data yang dikalkulasi harus tetap melebihi batas jumlah responden minimal dari aplikasi SEM. Setelah adanya penghapusan data outlier, data responden yang digunakan ada 174 Responden.

Teknik pengambilan sampel penelitian ini yaitu purposive sampling, yaitu pemilihan sampel berdasarkan karakteristik tertentu dari populasi, dalam hal ini adalah donatur yang telah membayar Zakat di Rumah Zakat lebih dari dua kali untuk memastikan hubungan yang keberlanjutan antara Rumah Zakat dan Muzakki. Hal ini seperti tercantum dalam pendahuluan Kuesioner yang disampaikan dalam gambar 4.1.

Penyampaian Kuesioner menggunakan aplikasi online Google Form dimana kuesioner dikirimkan ke donatur Rumah Zakat diseluruh Indonesia yang memiliki media sosial seperti facebook, instagram dan twitter yang terhubung dengan media sosial Rumah Zakat. Syarat untuk bisa mengisi kuesioner adalah donatur Rumah Zakat yang memiliki email pribadi.

\subsection{Pengukuran Variabel}

Data dari responden dikumpulkan dengan membuat skala pengukuran dan pemberian skor dari pernyataan kualitatif "sangat tidak setuju" dan "sangat setuju" untuk dijadikan data kuantitatif berupa skala interval genap, penggunaan skala genap agar ada kecondongan posisi ke salah satu arah skor antara skor besar atau ke skor kecil. Skor 1 (satu) untuk pernyataan "sangat tidak setuju" sampai dengan 8 (delapan) untuk skor "sangat setuju". Pilihan jawaban berupa multiple choice di google form. akan muncul seperti dibawah ini.

\section{Gambar 2}

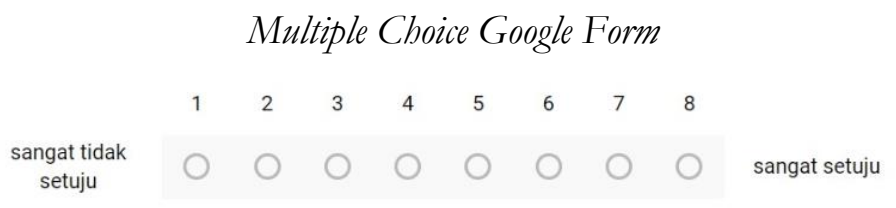

Sumber: Kuesioner Google Form, 2018

\subsection{Uji Validitas dan Reliabilitas Data}

Uji validitas merupakan pengujian kemampuan dari indikator-indikator untuk di ukur tingkat keakuratan sebuah konsep, artinya untuk mempertanyakan suatu konsep tersebut sudah valid atau belum. Uji ini melibatkan para ahli (ahli pemasaran, dan statistik) dan pihak yang berkompeten (calon responden) untuk memberi komentar, tanggapan dan saran terhadap indikator yang digunakan dalam item pertanyaan. ${ }^{21} \mathrm{Uji}$ validitas dilakukan dengan menghitung korelasi antar indikator yang menjadi penyusun variabel dengan skor total dari variabel untuk mengetahui keterkaitan antar variabel dengan skor total variabel. Dengan menggunakan metode menghitung skor total variabel yang kemudian dihitung dengan menggunakan microsoft Excel dengan rumus:

Rumus 1. Skor Total Variabel

$$
\text { R qi koreksi }=\frac{(\text { rqitotal })(\text { STDtotal })-\text { STDq }}{(\text { SRDq })^{2}+(\text { STDtotal })^{2}-2(\text { rqitotal })(\text { STDq })(\text { STDtotal })} \text { Dimana : }
$$

R qi total $=$ nilai total dari Korelasi Pearson

STDq $=$ standar deviasi masing-masing indikator

STD total $=$ total dari standar deviasi total.

\footnotetext{
${ }^{21}$ Sugiyono, Metode penelitian pendidikan: (pendekatan kuantitatif, kualitatif dan R \& D) (Bandung: Alfabeta, 2008$), 114$.
} 


\subsection{Uji Reliabilitas Data}

Reliabilitas didefinisikan sebagai indeks yang menunjukkan nilai alat ukur dapat dipercaya dan dapat memberikan jawaban yang sesuai dan konsisten. Alat ukur dapat dipercaya jika dapat menunjukkan hasil yang relatif sama atau konsisten dalam beberapa kali pelaksanaan pengukuran terhadap kelompok subyek yang sama. Pengukuran reliabilitas adalah menilai besaran composite reliability serta varianve extracted dari masing-masing konstruk dan dilakukan setelah mengetahui nilai regression Weights pada AMOS. Variabel dikatakan reliabel bila variabel tersebut mempunyai $\alpha$ cronbach $\geq 0,60$, bila kurang dari persyaratan tersebut, variabel akan dikeluarkan dari model. Composite Reliability diperoleh dari rumus:

Rumus 2. Construct Reliability

Construct-Reliability $=\frac{(\Sigma \text { Std.Loading })^{2}}{(\Sigma \text { Std.Loading })^{2}+\sum \varepsilon_{1} \Phi}$

Dimana:

Standar loading diperoleh dari standarized loading untuk setiap indikator (diambil dari perhitungan komputer, Excel, AMOS dan lain-lain) $є . \Phi$ adalah measurement error dari tiap-tiap indikator Variance Extraced diperoleh melalui rumus:

\section{Rumus 3. Variance Extracted

$$
\text { Variance }- \text { Extracted }=\frac{(\Sigma \text { Std.Loading })^{2}}{\left(\sum \text { Std.Loading }\right)^{2}+\sum \varepsilon_{1} \Phi}
$$

Teknik analisis yang digunakan penelitian ini ialah Structural Equation Model (SEM) yang dioperasikan melalui program AMOS versi 2.4 . Alasan dari penggunaan SEM, adalah karena SEM dapat digunakan untuk menguji kesesuaian sebuah model serta hubungan kausalitas antar faktor yang dibangun dan diamati ,dan juga menguji kesesuaian atau ketepatan model dengan data empiris yang telah diteliti. Proses pengambilan keputusan manajemen adalah sebuah sebuah proses yang multidimensional yang rumit dengan berbagai pola kausalitas yang berjenjang dan bertingkat, sehingga dibutuhkan sebuah model dan alat analisis yang mampu menjalankan penelitian multidimensional tersebut.

Manajemen dihadapkan pada situasi dan kondisi bahwa akan ada lebih dari satu variabel dependen yang harus dihubungkan agar diketahui derajad interrelasinya. Keunggulan dari aplikasi SEM dalam penelitian manajemen ini adalah karena kemampuannya untuk bisa mengkonfirmasi dimensi-dimensi dari berbagai konsep atau faktor yang lazim digunakan dalam manajemen organisasi serta mampu untuk mengukur pengaruh dari hubungan-hubungan yang secara teoritis ada.

Permodelan penelitian melalui SEM memungkinkan peneliti dapat menjawab pertanyaan penelitian yang bersifat dimensional maupun regresif. SEM dapat mengidentifikasi dimensidimensi konstruk atau konsep. SEM mampu mengukur pengaruh atau derajat hubungan dari faktor yang akan diidentifikasi dimensi-dimensinya.

Membuat modelan SEM yang lengkap perlu langkah-langkah berikut ini:

1. Pengembangan model dengan basis Teori

Pertama yang dilakukan adalah mengembangkan model yang menjustifikasi teori yang kuat, bisa melalui kajian pustaka dari sumber ilmiah mengenai dengan model yang sedang dikembangkan. SEM digunakan tidak untuk menghasilkan kausalitas, tetapi bisa untuk membenarkan adanya kausalitas teoritis dengan adanya uji empiris, karena itu pengkajian teori yang dalam dapat memunculkan justifikasi teoritis dari model yang diuji sebagai syarat utama dalam penggunaan SEM ini. 


\section{Pengembangan Diagram Alur (Path Diagram)}

Path diagram akan mempermudah peneliti melihat hubungan-hubungan kausalitas yang ingin diuji. Peneliti bekerja dengan "construk" atau "factor" yaitu konsep-konsep yang memiliki landasan teori yang cukup untuk menjelaskan berbagai bentuk hubungan. Konstruk-konstruk yang dibangun dalam model diagram alur dibagi menjadi dua kelompok, yaitu konstruk endogen dan konstruk eksogen.

a. Konstruk endogen merupakan faktor yang diprediksi oleh satu atau beberapa konstruk. Konstruk atau variabel endogen memprediksi satu atau beberapa konstruk endogen lain, konstruk endogen dapat berhubungan kausal dengan konstruk endogen lain.

b. Konstruk eksogen, atau independent variable atau source variables yang tidak diprediksi oleh variabel lain dalam model. Konstruk eksogen adalah konstruk atau variabel yang dituju oleh garis dengan satu ujung panah.

Model penelitian dikembangkan dan digambar pada sebuah diagram alur, kemudian konversi diagram alur ke dalam rangkaian persamaan. Persamaan yang dibangun terdiri :

a. Persamaan-persamaan struktural (Structural Equation)

Rumusan untuk pernyataan hubungan kausalitas antara berbagai konstruk, dan disusun dengan pedoman sebagai berikut:

Variabel Endogen $=$ Variabel Eksogen + Variabel Endogen + error

b. Persamaan Spesifikasi Model Pengukuran

Persamaan spesifikasi model pengukuran gunanya untuk menentukan rangkaian matriks yang memperlihatkan korelasi dari hipotesis antar konstruk atau variabel.

3. Model Pengembangan Struktural

4. Memilih matriks Input dan Estimasi Model.

Korelasi SEM atau Kovarian menggunakan matriks Kovarians / Varian matriks korelasi sebagai data input untuk semua estimasi yang dilakukannya. Matriks kovarians digunakan karena memiliki keunggulan dalam penyajian perbandingan yang valid antara sampel yang berbeda atau populasi yang berbeda, Hal tersebut tidak dapat disajikan korelasi. Matriks kovarian umumnya banyak digunakan untuk penelitian mengenai hubungan, karena standart error yang dilaporkan dari bermacam-macam penelitian menunjukkan angka kurang akurat bila digunakan sebagai input adalah matriks korelasi.

\section{Estimasi model}

Model dikembangkan dan input data telah dipilih, kemudian memilih program komputer yang digunakan untuk mengestimasi model, yaitu digunakan AMOS. Program AMOS adalah salah satu program yang canggih, handal dan mudah digunakan untuk menganalisis model kausalitas, (Ferdinand, 2002).

\section{Mengevaluasi kriteria Goodness-of-Fit}

Pada langkah evaluasi kesesuaian model, setelah melalui telaah berbagai kriteria goodness-of-fit (GFI). Kemudian melakukan evaluasi data yang akan digunakan dengan memenuhi asumsiasumsi SEM:

a. Ukuran sampel, ukuran sampel minimum adalah sebanyak 100 dan selanjutnya menggunakan perbandingan minimal 5 observasi untuk setiap estimated parameter.

b. Linearitas dan Normalitas, sebaran data dianalisis untuk melihat asumsi normalitas telah dipenuhi. Normalitas diuji dengan gambaran histogram data. Uji normalitas dilakukan untuk normalitas data multivariat yang memili variabel digunakan sekaligus dalam analisa akhir atau 
normalitas data tunggal.. Uji linearitas dilakukan dengan mengamati scatterplots dari data, dengan memilih pasangan data dan pola penyebarannya untuk pendugaan ada tidaknya linearitas.

c. Outliers, merupakan nilai observasi yang muncul dengan nilai-nilai ekstrim baik secara multivariat atau univariat, yang muncul karena kombinasi karakteristik unik yang dimilikinya dan terlihat terlalu sangat jauh berbeda dengan observasi lain.

d. Singularity dan Multicollinearity, multikolinearitas dideteksi dari determinan matriks kovarian. Nilai dari determinan matriks kovarian yang terlalu kecil memberi indikasi adanya problem singularitas atau multikolinearitas. Perlakuan data yang dapat diambil adalah mengeluarkan variabel yang penyebab singularitas tersebut.

\subsection{Uji statistik dan Uji Kesesuaian}

Beberapa cut off value dan indeks kesesuaiannya digunakan dalam pengujian sebuah model, apakah dapat diterima atau ditolak adalah sebagai berikut:

1. $\mathrm{X}^{2}$ - chi-square statistic. model dikatakan baik atau memuaskan bila nilai $\mathrm{X}^{2}$ nya rendah. semakin baik model tersebut, maka semakin kecil nilai chi-square statistic. Diterima berdasar dengan probability dengan cut off sebesar $\mathrm{P}>0,05$ atau $\mathrm{P}>0,01$.

2. RMSEA (The Root Mean Square Error of Approximation), menunjukkan goodness of fit (GFI) diharapkan bila model diestimasi dalam populasi. Indeks diterimanya model yang menunjukkan sebuah close fit dari model yang berdasarkan degree of freedom Nilai RMSEA yang lebih kecil atau sama dengan 0,08 .

3. GFI (Goodness of Fit Index), adalah ukuran non statistic dengan rentang nilai antara 0 (poor fit) sampai dengan 1,0 (perfect fit). Nilai tinggi dalam indeks ini menunjukkan sebuah "better fit."

4. AGFI (Adjusted Goodness of fit Index), adalah tingkat penerimaan yang direkomendasikan bila AGFI bernilai sama dengan atau lebih besar dari 0,90.

5. CMIN/DF, adalah The Minimum Sample Discrepancy Function dibagi dengan degree of freedom. nilai $\mathrm{x}^{2}$ relatif kurang dari 2.0 atau 3.0 adalah indikasi dari acceptable fit antara model dan data. CMIN/DF tidak lain adalah statistik chi square $\mathrm{x}^{2}$ relatif.

6. TLI (Trucker Lewis Index), adalah incremental index membandingkan model yang diuji terhadap baseline model, dnilai yang direkomendasikan adalah $>0,95$ dan nilai yang mendekati 1 menunjukkan a very good fit, sebagai acuan untuk diterimanya sebuah model

7. CFI (Comparative Fit Index), Nilai yang direkomendasikan adalah CFI lebih besar atau sama dengan 0,95 . Bila mendekati 1 , maka mengindikasi tingkat fit yang tertinggi .

\section{Hasil dan Pembahasan}

\subsection{Karakteristik Responden}

Subyek Penelitian ini adalah donatur Rumah Zakat sebagai pihak yang terlibat dengan implementasi CRM Rumah Zakat, sehingga menjawab pertanyaan indikator yang di harapkan penulis. Karakteristik responden pada penelitian ini ditinjau dari aspek jenis kelamin, usia, pendidikan terakhir, pekerjaan dan, pendapatan berdasarkan kategori yang tertinggi dari tiap aspek karakteristik. Jumlah sampel yang masuk yang telah mengisi kuesioner ada 201 responden yang dijabarkan dalam deskripsi indikator penelitian. Seluruh Responden ini harus melewati serangkaian uji Validitas dan Uji Realibilitas untuk mendapatkan sampel yang valid dan reliable dengan jumlah minimum sampel 100 responden berdasarkan jumalh indikator $20 \times 5=100$ sampel. 
Tabel 1. Karakteristik Responden

\begin{tabular}{lllll}
\hline No & Karakteristik & Katagori Tinggi & F & $\mathbf{\%}$ \\
\hline 1. & Jenis Kelamin & Laki-laki & 124 & $61,7 \%$ \\
\hline 2. & Usia & 25-35 tahun & 87 & $43,3 \%$ \\
\hline 3. & Pendidikan Terakhir & Sarjana (S1) & 124 & $61,7 \%$ \\
\hline 4. & Pekerjaan & Pegawai Negeri Sipil (PNS) & 98 & $48,8 \%$ \\
\hline 5. & Pendapatan & 3-5 Juta Rupiah & 88 & $43,8 \%$ \\
\hline
\end{tabular}

Sumber: data diolah , 2018

Responden didominasi oleh laki-laki sebesar 61\%. Hal ini di karenakan kewajiban mencari nafkah dari pihak laki-laki. Namun penulis menemukan 77 orang responden atau sebesar 38,3\% dari perempuan yang memiliki penghasilan dan bisa membayar zakat pribadi. responden berdasarkan usia ditampilkan terbesar pada kategori usia 25 - 35 tahun sebesar 87 orang (43.3\%). Usia dibawah 18 Tahun dan diatas 60 tahun tidak ada. Responden lebih banyak diusia produktif, yaitu 18 - 25 tahun ada 14 orang (7\%). 36 - 45 tahun dikatagori kedua terbesar yaitu 85 orang $(42,3 \%)$ dan 46 - 60 tahun ada 15 orang (7,5\%). lulusan sarjana (S1) yaitu sebesar 124 orang (61,7\%). Diikuti lulusan Pascasarjana S2 sebesar 30 orang (14,9\%), kemudian katagori SMA sederajat sebesar 28 orang $(13,9 \%)$. Katagori SMP sederajat dan Lainnya sama-sama 1 responden (0,5\%). didominasi oleh PNS sebesar 98 orang (48,8\%), diikuti oleh Pegawai swasta sebesar 56 orang atau sebesar $27,9 \%$. Kemudian kategori berikutnya adalah Wiraswasta sebesar 23 orang $(11,4 \%)$. Ibu Rumah Tangga 19 orang $(9,5 \%)$ dan lainnya 3 orang (1,5\%). Pelajar atau mahasiswa ada 2 orang responden (1\%). adalah pada katagori 3 - 5 juta rupiah yaitu sebesar 43,8 \%. Diikuti oleh katagori lebih dari 5 juta rupiah sebesar 63 responden (31,3\%). Kemudian $1-3$ juta rupiah sebanyak 44 orang $(21,9 \%)$ dan kurang dari 1 juta sebanyak 6 orang $(3 \%)$.

Analisis indikator penelitian menggunakan SEM AMOS mengenai presepsi Responden terhadap penerapan konsep Customer Relationship Management (CRM) di Rumah Zakat terhadap Customer Relationship Quality (CRQ) dan Customer Lifetime Value (CLV), untuk mendapatkan persepsi responden pada Rumah Zakat terhadap item item pernyataan responden berdasarkan 20 indikator penelitian menggunakan software.

Tabel 2. Deskripsi Indikator Penelitian

\begin{tabular}{|c|c|c|c|c|c|c|c|c|c|c|c|c|c|c|}
\hline No & $\begin{array}{l}\text { Konstruk } \\
\text { Penelitian }\end{array}$ & $\begin{array}{l}\text { Dimensi } \\
\text { Konstruk }\end{array}$ & Notasi & 1 & 2 & 3 & 4 & 5 & 6 & 7 & 8 & Resp. & Total & $\begin{array}{l}\text { Rata- } \\
\text { Rata }\end{array}$ \\
\hline \multirow[t]{10}{*}{1.} & \multirow{10}{*}{$\begin{array}{l}\text { Customer } \\
\text { Relationship } \\
\text { Management } \\
(\mathrm{CRM})\end{array}$} & $\begin{array}{l}\text { Continuity } \\
\text { Marketing }\end{array}$ & X.1 & 0 & 0 & 0 & 4 & 20 & 77 & 60 & 40 & 201 & 1218 & 6.56 \\
\hline & & $\begin{array}{l}\text { One to One } \\
\text { Marketing }\end{array}$ & X.2 & 0 & 0 & 1 & 0 & 5 & 36 & 121 & 38 & 201 & 1370 & 6.94 \\
\hline & & Partnering Program & X.3 & 0 & 0 & 0 & 1 & 6 & 53 & 114 & 27 & 201 & 1336 & 6.8 \\
\hline & & Customer Database & X.4 & 2 & 0 & 1 & 1 & 1 & 72 & 95 & 29 & 201 & 1338 & 6.68 \\
\hline & & $\begin{array}{l}\text { Electronic Point of } \\
\text { Sales }\end{array}$ & X.5 & 1 & 0 & 1 & 3 & 5 & 58 & 102 & 31 & 201 & 1326 & 6.72 \\
\hline & & $\begin{array}{l}\text { Sales Force } \\
\text { Automotion }\end{array}$ & X.6 & 1 & 1 & 1 & 1 & 5 & 57 & 116 & 19 & 201 & 1316 & 6.67 \\
\hline & & $\begin{array}{l}\text { Customer Service } \\
\text { Helpdesk }\end{array}$ & X.7 & 1 & 1 & 2 & 5 & 8 & 60 & 104 & 20 & 201 & 1277 & 6.55 \\
\hline & & Call Centers & X.8 & 0 & 0 & 1 & 1 & 7 & 67 & 102 & 23 & 201 & 1307 & 6.68 \\
\hline & & System Integration & X.9 & 0 & 0 & 0 & 2 & 9 & 68 & 94 & 28 & 201 & 1298 & 6.68 \\
\hline & & Social Media & X.10 & 0 & 1 & 1 & 4 & 10 & 61 & 102 & 22 & 201 & 1277 & 6.6 \\
\hline
\end{tabular}




\begin{tabular}{|c|c|c|c|c|c|c|c|c|c|c|c|c|c|c|}
\hline \multirow[t]{6}{*}{2.} & \multirow{6}{*}{$\begin{array}{l}\text { Customer } \\
\text { Relationship } \\
\text { Quality } \\
\text { (CRQ) }\end{array}$} & Service & Z.1 & 0 & 0 & 2 & 0 & 9 & 57 & 110 & 23 & 201 & 1302 & 6.7 \\
\hline & & Solution & Z.2 & 0 & 0 & 1 & 2 & 5 & 60 & 107 & 26 & 201 & 1328 & 6.73 \\
\hline & & Experience & Z.3 & 0 & 1 & 1 & 0 & 2 & 62 & 113 & 22 & 201 & 1344 & 6.74 \\
\hline & & Trust & Z.4 & 0 & 1 & 0 & 1 & 5 & 65 & 107 & 22 & 201 & 1321 & 6.7 \\
\hline & & Satisfaction & Z.5 & 0 & 0 & 1 & 2 & 5 & 55 & 110 & 28 & 201 & 1335 & 6.77 \\
\hline & & Commitment & Z.6 & 0 & 0 & 2 & 2 & 3 & 58 & 111 & 25 & 201 & 1339 & 6.74 \\
\hline \multirow[t]{4}{*}{3.} & \multirow{4}{*}{$\begin{array}{l}\text { Customer } \\
\text { Lifetime } \\
\text { Value } \\
\text { (CLV) }\end{array}$} & Usage Quantity & Y.1 & 0 & 0 & 2 & 1 & 4 & 58 & 104 & 32 & 201 & 1342 & 6.78 \\
\hline & & Loyalty & Y.2 & 0 & 1 & 2 & 0 & 7 & 63 & 101 & 27 & 201 & 1309 & 6.69 \\
\hline & & Word of Mouth & Y.3 & 0 & 1 & 2 & 2 & 4 & 60 & 113 & 19 & 201 & 1319 & 6.66 \\
\hline & & Purchase Intention & Y.4 & 0 & 3 & 0 & 0 & 5 & 51 & 105 & 37 & 201 & 1343 & 6.81 \\
\hline
\end{tabular}

Tabel 5.3.1.Deskripsi Indikator Penelitian mengungkapkan sebaran data responden dalam penelitian, dimana jumlah responden memilih skor dari indikator di akumulasikan dalam tabel 5.3.1. , kemudian dibuat nilai total dan rata-rata dari total indikator.

\subsection{Uji Validitas dan Realibilitas}

Menurut Sekaran (1992:287) jika nilai Cronbach's alpha lebih kecil dari 0,60 dikategorikan poor, dalam rentang 0,70 (0,60 sampai 0,80) dikategorikan dapat diterima; dan di atas 0,80 dikategorikan baik. Hasil perhitungan construct reliability dengan menggunakan aplikasi Excel dan SPSS untuk setiap konstruk disajikan pada Tabel 3 berikut:

Tabel 3. Nilai Construct Reliability Setiap Konstruk

\begin{tabular}{lll}
\hline Konstruk & Construct Reliability & Keterangan \\
\hline CRM & 0,863 & Baik \\
\hline CRQ & 0,905 & Baik \\
\hline CLV & 0,888 & Baik \\
\hline
\end{tabular}

Sumber: Data Primer Diolah, 2018

Berdasarkan hasil perhitungan tersebut, karena tidak ada nilai construct reliability yang nilainya di bawah 0,60 maka semua konstruk dalam penelitian ini layak untuk digunakan dalam model.

Validitas indikator untuk menyusun konstruk dapat dilihat dari loading factornya. Berdasarkan Uji Validitas model menghasilkan loading factor yang ditunjukkan di tabel dibawah ini:

Tabel 4. Loading Factor Indikator Model Modifikasi

\begin{tabular}{|c|c|c|c|c|}
\hline No & Konstruk Penelitian & Dimensi Konstruk & Notasi & $\begin{array}{c}\text { Loading } \\
\text { factor }\end{array}$ \\
\hline \multirow[t]{7}{*}{1.} & \multirow{7}{*}{$\begin{array}{l}\text { Customer } \\
\text { Relationship } \\
\text { Management (CRM) }\end{array}$} & Continuity Marketing & X.1 & 0,561 \\
\hline & & One to One Marketing & X.2 & 0,497 \\
\hline & & Partnering Program & X.3 & 0,599 \\
\hline & & Customer Database & X.4 & 0,632 \\
\hline & & $\begin{array}{l}\text { Electronic Point of } \\
\text { Sales }\end{array}$ & X.5 & 0,673 \\
\hline & & Sales Force Automotion & X.6 & 0,587 \\
\hline & & $\begin{array}{l}\text { Customer Service } \\
\text { Helpdesk }\end{array}$ & X.7 & 0,701 \\
\hline
\end{tabular}




\begin{tabular}{|c|c|c|c|c|}
\hline & & Call Centers & X.8 & 0,690 \\
\hline & & System Integration & X.9 & 0,782 \\
\hline & & Social Media & X.10 & 0,693 \\
\hline 2. & Customer & Service & Z.1 & 0,729 \\
\hline & Relationship Quality & Solution & Z.2 & 0,683 \\
\hline & & Experience & Z.3 & 0,675 \\
\hline & & Trust & Z.4 & 0,685 \\
\hline & & Satisfaction & Z.5 & 0,749 \\
\hline & & Commitment & Z.6 & 0,687 \\
\hline 3. & Customer Lifetime Value & Usage Quantity & Y.1 & 0,759 \\
\hline & $(\mathrm{CLV})$ & Loyalty & Y.2 & 0,722 \\
\hline & & Word of Mouth & Y.3 & 0,714 \\
\hline & & Purchase Intention & Y.4 & 0,625 \\
\hline
\end{tabular}

Sumber : output SEM AMOS 24 yang diolah

\subsection{Evaluasi Normalitas}

Evaluasi normalitas data dilakukan dengan menggunakan kriteria critical ratio skewness value sebesar $\pm 2,58$ pada tingkat signifikansi $0,01(1 \%)$. Data dikatakan berdistribusi normal jika nilai critical ratio skewness value di bawah harga mutlak 2,58 . Salah satu cara untuk mengatasi adanya data nonnormal secara multivariate adalah menggunakan prosedur yang dikenal dengan "bootstrap". Teknik bootstrap merupakan prosedur resampling dimana sampel asli diperlakukan sebagai populasi.

Sampel dari 201 Responden masih menghasilkan data outlier sehingga diperlukan Uji Mahalanobis yang mengahasilkan 174 Sampel. Evaluasi reestimasi SEM dilakukan dengan data sejumlah 174, sudah memenuhi aturan bahwa untuk Amos sebaiknya diantara 100-400. Berdasarkan hasil perhitungan yang ditunjukkan pada Tabel 5.4.2, ternyata nilai multivariate output AMOS 24 menunjukkan angka 5,032 yang nilainya lebih dari 2,58, sehingga secara multivariate data kurang normal.

Gambar 3. Model Amos dengan penghapusan data Outlier.

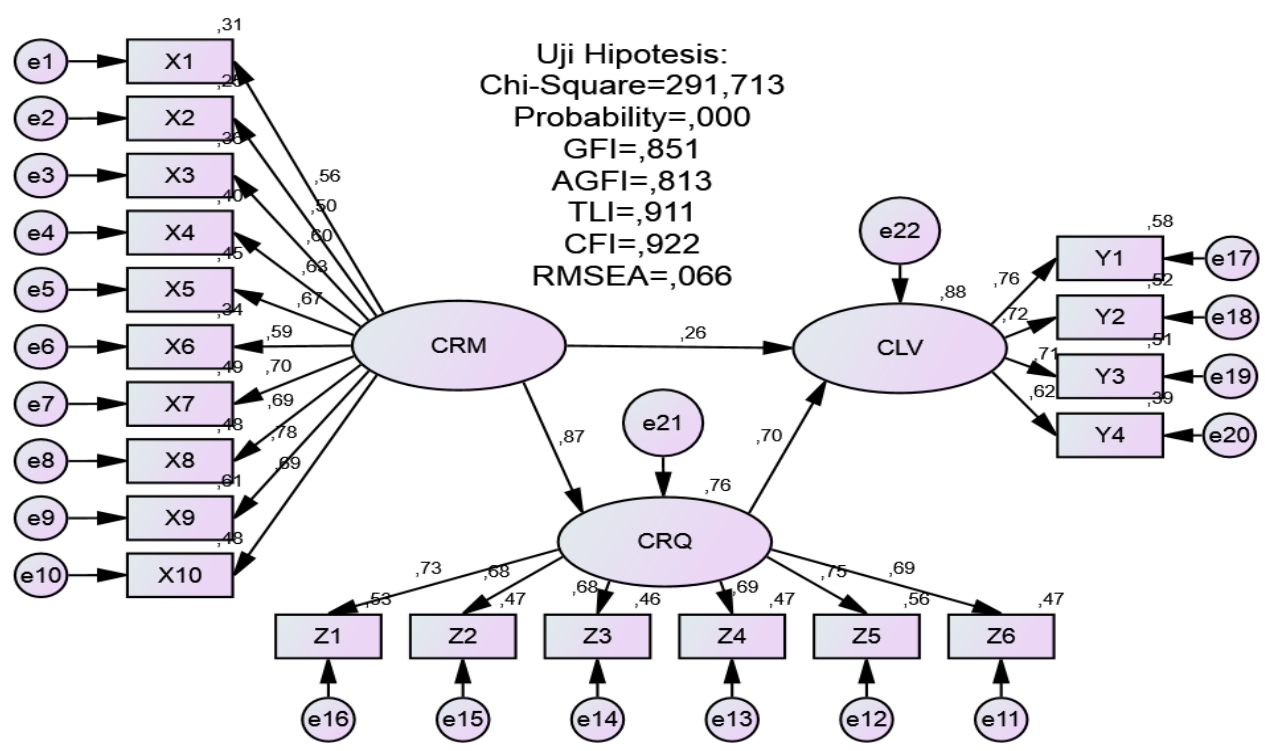

Sumber: Output Amos 24 yang diolah 
Gambar 5.6.1. telah menunjukkan nilai loading factor model amos dengan setelah menghapus data outlier dari responden. Hal ini menyebabkan perubahan nilai loading factor dari model yang ditunjukkan pada tabel 5.6.1.

Full model diatas kemudian di re-Estimasi dengan menggunakan data yang sudah dihapuskan dari data outlier sebanyak 174 data responden. Kemudian hasil dari Re-Estimasi dalam tabel Goodness of Fit Index.

Tabel 5. Goodness of fit index Model tanpa Outlier

\begin{tabular}{llll}
\hline $\begin{array}{l}\text { Goodness of } \\
\text { fit Index }\end{array}$ & Cut off value & $\begin{array}{l}\text { Hasil } \\
\text { analisis }\end{array}$ & Evaluasi Model \\
\hline $\mathrm{X}^{2}$-Chi Square & $\begin{array}{l}<\text { nilai tabel } \mathrm{X}^{2} \\
(\mathrm{df}=167)=198,1542\end{array}$ & 291,713 & Poor fit \\
\hline $\begin{array}{l}\text { Significance } \\
\text { Probability }\end{array}$ & $\geq 0,05$ & 0,000 & Poor fit \\
\hline CMIN/DF & $\leq 2.00$ & 1,747 & Fit \\
\hline RMSEA & $\leq 0,08$ & 0,066 & Fit \\
\hline GFI & $\geq 0,90$ & 0,851 & Marginal fit \\
\hline AGFI & $\geq 0,90$ & 0,813 & Marginal fit \\
\hline TLI & $\geq 0,95$ & 0,911 & Marginal fit \\
\hline CFI & $\geq 0,95$ & 0,922 & Marginal fit \\
\hline
\end{tabular}

Sumber: Output Amos 24 yang diolah

Model diatas masih memiliki kelemahan dengan adanya Output yang tidak fit. Untuk itu perlu modifikasi berdasarkan modification indices, namun karena pengajuan teori yang menyatakan hubungan antara indikator tidak digunakan, maka modifikasi tidak dilakukan.

\section{Hasil Pengujian Hipotesis}

Tabel 6. Loading Factor Variabel

\begin{tabular}{lllllll}
\hline CRQ $<---$ & CRM &, 826 &, 112 & 7,400 & $* * *$ & par_18 \\
\hline CLV $<---$ & CRM &, 287 &, 174 & 1,647 &, 100 & par_19 \\
\hline CLV $<---$ & CRQ &, 799 &, 197 & 4,053 & $* * *$ & par_20 \\
\hline \hline
\end{tabular}

Sumber: Output AMOS 24

Berdasarkan Tabel 5.6.4. Maka dapat ditunjukkan bahwa nilai loading factor CRM terhadap CLV yang rendah yaitu sebesar 0,287. Pengaruh CRM ke CLV menjadi tidak signifikan sehingga Hasil Uji Hipotesis H1 ditolak. Rangkuman Uji Hipotesis ditunjukkan pada tabel 7

Tabel 7. Tabel Uji Hipotesis

\begin{tabular}{llccll}
\hline No. & \multicolumn{1}{c}{ Hipotesis } & C.R & $\mathbf{P}$ & $\begin{array}{r}\text { Hasil Uji } \\
\text { Hipotesis }\end{array}$ & $\begin{array}{l}\text { Kekuatan } \\
\text { pengaruh }\end{array}$ \\
\hline H1 & $\begin{array}{l}\text { CRM mempunyai pengaruh positif } \\
\text { terhadap tingkat CLV }\end{array}$ & 1,647 & 0,100 & ditolak & 0,287 \\
\hline
\end{tabular}




\begin{tabular}{llllll}
\hline H2 & $\begin{array}{l}\text { CRM mempunyai pengaruh positif } \\
\text { terhadap tingkat CRQ }\end{array}$ & 7,400 & 0,000 & Diterima & 0,826 \\
\hline H3 & $\begin{array}{l}\text { CRQ mempunyai pengaruh positif } \\
\text { terhadap tingkat CLV }\end{array}$ & 4,053 & 0,000 & Diterima & 0,799 \\
\hline H4 & $\begin{array}{l}\text { CRM mempunyai pengaruh positif } \\
\text { terhadap tingkat CLV dengan } \\
\text { intervensi CRQ }\end{array}$ & 1,745 & 0,000 & Diterima & 0,503 \\
\hline
\end{tabular}

Sumber: Diolah dari output AMOS 24

CRM mempunyai pengaruh positif terhadap tingkat CLV dengan intervensi CRQ. nilai signifikansi berasal dari Total effect CRM-CRQ-CLV.

Total effect $C R M-C R Q-C L V=$

Direct effect $C R M-C R Q \times$ indirect effect $C R M-C L V=0,826 \times 0,609=0,503$

Bentuk Model Dasar dari Penelitian ditunjukkan berdasarkan gambar. 5.6.3.1

\section{Gambar 3}

\section{Model Hasil Penelitian}

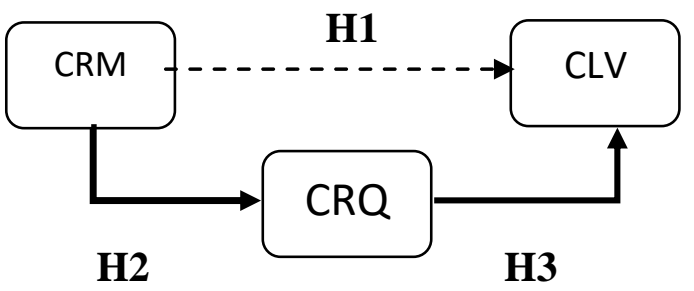

H4

Konsep dasar analisis yang penggunaan variabel mediator apabila variabel independen (eksogen) mampu mempengaruhi variabel dependen (endogen) melalui variabel lain dalam model SEM yang disebut dengan variabel mediator $(\mathrm{M})$. Artinya variabel independen $(\mathrm{X})$ mempengaruhi variabel mediator dan variabel mediator $(\mathrm{M})$ dapat mempengaruhi variabel dependen $(\mathrm{Y})$. Dari bentuk model gambar bentuk hasil penelitian dari Analisis CRM terhadap CRQ dan CLV merupakan bentuk dari Nilai CRM->CLV yang tidak signifikan menyebabkan aliran effect dari CRM-CRQ-CLV merupakan bentuk hubungan fullmediation, jadi hubungan CRM ke CLV di mediasi penuh oleh CRQ.

\section{Implikasi Manajemen}

Pengaruh hubungan CRM terhadap CRQ dan CLV Rumah Zakat, maka berimplikasi terhadap indikator penelitian yang perlu diperhatikan.

Continuity Marketing. Penggunaan masih i-card perlu terus dikampanyekan untuk terus memperkuat hubungan CRM dengan pelanggan, karena manfaat yang diberikan produk ini terhadap Muzakki sangat besar. Manfaat yang didapat dari continuity marketing antara lain:

1. Membangun database pelanggan yang luas untuk memungkinkan perusahaan benar-benar memahami pelanggan dan mengantisipasi kebutuhan mereka.

2. Membangun hubungan jangka panjang dengan pelanggan.

3. Meningkatkan penjualan dan margin perusahaan.

4. Meningkatkan loyalitas pelanggan. 
One to One Marketing. Rekaman donasi kurang signifikan untuk mempengaruhi hubungan Rumah Zakat dengan Muzakki sebagai pelanggan, Hal ini harus terus dikampanyekan, oleh Rumah Zakat karena membantu untuk mengetahui penyaluran donasi zakat dari muzakki dan memperlihatkan kinerja dari Rumah Zakat untuk menyalurkan donasi zakat ke masyarakat yang membutuhkan.

One-to-One Marketing adalah teknik pemasaran produk dengan memberikan produk dan jasa pada pelanggan sesuai dengan hasil identifikasi terhadap preferensi dan kebutuhan pelanggan masing-masing. Teknik ini menyadari konsep customer lifetime value, dimana pelanggan yang melakukan pembelian berulang dan loyal akan memberikan nilai besar terhadap perusahaan. Supaya muzakki Rumah Zakat mau melakukan pembayaran zakat kembali di rumah zakat, maka kuncinya dengan one-to-one marketing, memenuhi kebutuhan pelanggan secara spesifik.

One-to-one marketing terdiri dari 2 jenis, yakni customization dan Personalization. Customization adalah ketika pelanggan proaktif memilih satu elemen marketing mix atau lebih bagi mereka. Jadi bedanya dengan personalization adalah, disini pelanggan akan berperan banyak untuk memilih. Jenis layanan rumah zakat yang terdiri dari senyum lestari, senyum juara, senyum mandiri, senyum sehat, empowered ramadhan dan superqurban. Donatur bisa memilih dari program nasional itu, atau membuat program lokal untuk mnyerahkan donasi dengan program yang disesuaikan dengan kemampuan program kantor cabang rumah zakat.

Personalization terjadi ketika perusahaan memutuskan marketing mix yang sesuai, berdasar dengan kesimpulan data pelanggan yang diperoleh. Personalization memiliki keunggulan, antara lain kepuasan donator rumah zakat yang lebih tinggi dan donasi yang juga akan lebih tinggi. Kepuasan diharapkan akan meningkat, karena rumah zakat melaksanakan marketing mix yang relevan dengan data donatur.

Partnering Program. Pengaruh program kemitraan Rumah Zakat cukup baik untuk meningkatkan hubungan baik antara Rumah Zakat dengan Muzakki, namun masih perlu terus ditingkatkan dan harus terus disosialisasikan ke masyarakat pada umumnya dan Muzakki Rumah Zakat pada Khususnya.

Program kemitraan (partnering program) merupakan program dimana perusahaan melakukan hubungan kemitraan dalam bentuk kerjasama dengan pihak lain untuk melayani dan memenuhi kebutuhan pelanggan. Saat ini Rumah Zakat telah menggandeng mitra yang dirangkum di website.https://www.rumahzakat.org/category/mitra-korporat/com.

Rumah zakat bermitra dengan partner yang melayani donatur untuk mendapatkan kemudahan bertransaksi dengan cara melalui perbankan dan online. Contohnya dengan tokopedia, bukalapak, kitabisa.com dan lain-lain. Rumah zakat juga memiliki mitra untuk penyaluran donasi seperti sekolah-sekolah, panti asuhan, panti jompo, rumah sakit, lembaga pelatihan dan lain-lain.

Customer Database. Kepedulian Muzakki untuk mengisi data sudah cukup bagus, tetapi masih perlu ditingkatkan lagi. Database yang lengkap dan adalah senjata ampuh bagi rumah zakat. Karena database memiliki banyak manfaat, seperti: 1.Petunjuk arah penjualan. Database pelanggan dapat rumah zakat gunakan untuk petunjuk arah penjualan agar produk rumah zakat dapat memasuki donatur yang tepat (wajib zakat yang mampu). Aktivitas pemasaran akan berjalan efisien dan cepat jika rumah zakat telah melengkapi database prospek muzakki yang menjadi target donatur rumah zakat.

Electronic Point of Sales. Kemudahan pembayaran zakat di Rumah Zakat melalui layanan perbanakan sudah cukup bagus dan perlu ditingkatkan seiring, kampanye pemerintah untuk meningkatkan transaksi Non Tunai. Peralatan dan software penerimaan zakat sudah dimiliki oleh Rumah Zakat dengan kerjasama perusahan ZAINS. Hal ini untuk memudahkan pembukuan penerimaan dan penyaluran zakat ke masyarakat yang membutuhkan donasi zakat. Apalagi 
dengan kondisi rumah zakat yang telah bisa menerima zakat baik berbentuk tunai, transfer perbankan dan online.

Sales Force Automotion Tingkat Penggunaan Aplikasi Online untuk pembayaran Zakat sudah cukup bagus dan perlu lebih ditingkatkan. Apalagi sekarang Rumah Zakat sudah menggunakan website https://www.rumahzakat.org/donasi/ untuk menerima Zakat online, tanpa harus ke ATM atau pergi ke kantor Cabang Rumah Zakat terdekat.

Customer Service Helpdesk loading factornya sebesar 0,701 terhadap variabel CRM. Layanan Helpdesk Rumah Zakat cukup bagus dan mempengaruhi hubungan Rumah Zakat dengan Muzakki dengan baik. Help Desk adalah bagian dari suatu perusahaan termasuk rumah zakat, yang menyelesaikan sebuah masalah atau memberikan solusi yang dialami pengguna atau pelanggan baik itu dari pihak eksternal (bukan karyawan perusahaan itu), maupun internal (karyawan perusahaan itu sendiri). Helpdesk dapat memberi jawaban atau solusi atas pertanyaan/komplain dalam waktu yang singkat. Helpdesk dapat mengecek status permasalahan yang ada dan mengatur pembagian tugas penanganan permasalahan tersebut. Helpdesk dapat meningkatkan efisiensi unit kerja dalam menangani pertanyaan atau complain dari end user. Helpdesk rumah zakat bergabung atau berkaitan dengan Callcenter dari rumah zakat.

Call Centers Layanan Call Center Rumah Zakat cukup bagus dan menguatkan pengaruh hubungan Rumah Zakat dengan Muzakki dengan hampir baik. Manfaat Call Center bagi rumah zakat antara lain. Memberi pelayanan informasi terkait produk layanan rumah zakat yang dibutuhkan oleh donator. Seorang call center perusahaan harus menguasai produk baik barang ataupun jasa yang ditawarkan perusahaan kepada customer atau biasa disebut Product Knowledge. Hal ini berkaitan dengan kesesuaian informasi yang diberikan call center Rumah zakat kepada donator. Call center Sebagai perpanjangan tangan dari perusahaan untuk memberi pelayanan kepada customer, Dalam upaya untuk menjadi perusahaan yang dikenal baik oleh customer, maka call center mampu memberi manfaat yang cukup besar bagi perusahaan termasuk rumah zakat sebagai LAZ.

System Integration. Banyak keuntungan dan manfaat yang bisa didapat ketika rumah zakat mengupgrade atau mengganti sistem IT yang sudah lama dan kuno, rumah zakat bisa menggunakan sistem baru dengan single platform yang dapat menangani pengolahan data dengan aman dan reliable. manfaat yang paling utama dalam penggunaan single platform system, merampingkan, meringkas, melindungi dan mempercepat proses supply chain dan juga bisnis operation Rumah zakat. rumah zakat dapat mengurangi kelemahan sistem atau resiko-resiko, meningkatkan customer service, hemat operating cost.

Ada juga manfaat untuk meningkatkan visibilitas sistem Rumah Zakat, single source of truth, jadi Rumah zakat tidak kewalahan untuk mencari data di berbagai sistem yang berbeda, contoh : jika ada donatur yang menanyakan status dari donasi mereka kepada rumah zakat, maka otomatis customer service dapat menyampaikan data kepada donatur. Resiko kesalahan dan keterlambatan akan meningkat dan memakan waktu lebih banyak, jika karyawan harus mencari dibeberapa sistem yang berbeda..

Social Medial Saat ini, pelanggan menggunakan media sosial untuk mendiskusikan, memberikan pujian dan bahkan menghujat perusahaan/organisasi dari berbagai bidang. Jadi, ada cara untuk bergabung dan masuk dalam sebuah diskusi/percakapan yang pada akhirnya bertujuan untuk melayani pelanggan dengan lebih baik, mengidentifikasi peluang baru dan menjaga Brand Rumah Zakat di posisi yang baik dari spektrum sentimen sosial.

Service/ CRQ dibentuk dari service yang diberikan karyawan kepada pelanggan, Rumah Zakat harus meperhatikan layanan yang berkualitas dan prima untuk membentuk hubungan pelanggan yang berkualitas. Menurut Zeithhaml, Parasuraman \& Berry (dalam Hardiansyah 2011:46) untuk mengetahui kualitas pelayanan yang dirasakan secara nyata oleh konsumen, ada indikator kualitas 
pelayanan yang terletak pada lima dimensi kualitas pelayanan atau SERVQUAL, yaitu: a.tangible (berwujud) b.Reliabelity (kehandalan) c.Responsiviness (ketanggapan) d. Assurance (jaminan) e.emphaty (Empati).

Solution. Perhatian terhadap solusi muncul dari adanya komplain pelanggan. Rumah Zakat harus memperhatikan komplain dan memunculkan solusi atas permasalahan pelanggan. Saat ini Rumah Zakat telah menyediakan sarana dengan kebaradaan call center dengan telepon atau dalam web rumah zakat. Bahkan rumah zakat berusaha mengatasi komplen yang masuk melalui media sosial maupun web komunitas seperti kaskus ataupun blog pribadi.

Pelanggan yang melakukan komplain pastinya menginginkan suatu penyelesaian masalah. Komplain yang datang dari pelanggan biasanya datang karena pelanggan merasa ada yang dirugikan atau merasa tidak puas dengan kualitas pelayanan yang Anda berikan. Oleh karena itu, rumah zakat harus bisa memberikan solusi yang baik kepada donatur sehingga kedua belah pihak tidak ada yang dirugikan baik materil maupun non materil.

Experience. Faktor pengalaman atau experience sebagai faktor penting untuk menarik pelanggan baru dan mempertahankan pelanggan lama. Rumah Zakat harus menyampaikan pengalaman donatur lama selama menggunakan layanan rumah zakat, serta menyampaikan laporan penyampaian ke pada para mustahiq yang menerima zakat sebagai pertanggungjawaban kepada para donatur untuk dapat memperoleh kepercayaan dan akhirnya donatur bersedia membayar zakat kembali di rumah zakat.

Trust / Trust merupakan faktor penting yang diperhatikan oleh rumah zakat. Trust merupakan nilai dari brand rumah zakat, karena rumah zakat bekerja berdasarkan amanah dari donatur muzakki yang mempercayakan zakatnya untuk disalurkan rumah zakat ke mustahiq yang berhak mendapatkan. Sheth (2004) mendefinisikan kepercayaan sebagai berikut "Trust is a willingness to rely on the ability, integrity and motivation of the other party to act to serve the needs and interests as a agreed upon implicitly or explicitly".

Satisfaction. Kepuasan pelanggan merupakan faktor utama perusahaan bisa bertahan, termasuk rumah zakat yang merupakan lembaga amal zakat yang merupakan peruahaan nirlaba. Dengan mempertimbangkan CRQ digunakan dalam perusahaan, rumah zakat dapat mengukur kepuasan donatur sebagai pelanggan rumah zakat. Rumah zakat mendapatkan informasi kepuasan pelanggan berdasarkan informasi dari penghargaan majalah SWA 1 Champion Indonesia Original Brand (IOB) . Empat variabel yang diukur dalam survei IOB ini adalah satisfaction, loyalty, advocation, dan local brand competitiveness level. Saat ini penulis belum menemukan survey atau jajak pendapat yang mengukur tingkat kepuasan pelanggan yang berasal dari rumah zakat sendiri.

Commitment/Kualitas layanan berpengaruh positif signifikan terhadap kepercayaan dan komitmen nasabah, yang pada gilirannya akan berpengaruh secara positif signifikan terhadap loyalitas nasabah (Setiawan,2007). Komitmen donatur rumah zakat merupakan bentuk ikatan yang muncul dari hubungan pelanggan yang berkualitas. Donatur yang berkomitmen adalah donatur yang mau kembali menggunakan jasa layanan rumah zakat.

Tujuan akhir dari CRM adalah meningkatkan CLV. Dimana CLV merupakan keuntungan dari usaha melaksanakan CRM atau manajemen hubungan pelanggan dengan menjaga kualitas hubungan dengan pelanggan.

Usage Quantity. Dengan Rumah Zakat telah membuat kriteria customer berdasarkan tingkat besarnya pembayaran dan seberapa sering melakukan pembayaran. Untuk pelanggan premium pasti harus diutamakan karena kadang mereka mengisi pemasukan yang sangat besar dibandingkan pelanggan kecil. Namun pelayanan standar harus tetap memuaskan donatur kecil. Diharapkan perhatian terhadap CRM dan CRQ pada rumah zakat dapat membantu meningkatkan penggunaan layanan rumah zakat oleh donatur zakat atau muzakki. 
Loyalty Loyalitas pelanggan rumah zakat yaitu para muzakki dan donatur diharapkan terus meningkat dengan perhatian khusus rumah zakat dengan pelaksanaan CRM dan CRQ. Sehingga donatur tidak beralih ke LAZ lain atau membayar sendiri ke mustahiq, untuk tetap memudahkan dalam melaksanakan ibadah berzakat, berinfaq dan bersedeqah. Tanpa harus merepotkan diri, dan ditangani oleh rumah zakat yang amanah, terpercaya dan professional

Word of Mouth. Ada sebuah tulisan, di web rumahzakat.org "jangan abaikan ngrumpi”, karena hal ini bisa menjadi bencana kalau tidak dikelola dengan baik. Riak riak gelombang kecil ini, bisa menjadi tsunami yang dapat menenggelamkan pulau usaha. Rumah Zakat cukup berusaha untuk menangani complain yang muncul di permukaan baik dari call center, konsultasi syariah, bahkan melalui jalur sosial media, blog, maupun web komunitas. Namun gossip-gosip yang tidak terdeteksi secara langsung bisa menjadi gelombang yang massif yang bisa merusak nama baik rumah zakat. Rumah zakat harus bekerja ekstra keras untuk bisa berpromosi dan bersosialisasi tentang mencegah isu-isu negatif serta memberikan usaha lebih agar pembicaraan positif yang lebih berkembang dalam pembicaraan masyarakat. Akhirnya ada promosi gratis yang diberikan dengan rekomendasi dari para pelanggan yang sudah puas dengan layanan yang dioberikan rumah zakat.

Purchase Intention. Usage Quantity, Loyality, dan Word of Mouth yang baik, membuka peluang baru rumah zakat untuk membuka program layanan baru yang bisa dikelola rumah zakat sebagai lembaga amal zakat swasta. Contohnya saat ini rumah zakat memang belum mengelola harta wakaf. Dimana wakaf adalah asset yang disumbangkan umat islam untuk kemaslahatan. Sebenarnya dari hukum agama LAZ memang boleh mengelola zakat dan mendapat landasan hukum Negara didalam UU tentang LAZ. Citra dari rumah zakat yang sudah baik ini bisa memberikan peluang rumah zakat untuk membuka layanan wakaf.

\section{Penutup}

\subsection{Kesimpulan}

Berdasarkan uraian tersebut di bab-bab sebelumnya, maka dapat disimpulkan dari hasil penelitian yaitu:

a) Variabel CRM memiliki pengaruh positif terhadap CLV bahwa pengaruh tersebut tidak signifikan karena sehingga pengaruh positif tidak terdukung. Adanya pengaruh yang berkorelasi positif namun tidak signifikan antara CRM terhadap CLV sehingga Hipotesis 1 ditolak . Variabel CRM tidak bisa langsung berpengaruh signifikan kepada CLV apabila ada variabel CRQ. Hal ini menunjukkan manajemen hubungan pelanggan tidak akan mampu langsung mempengaruhi nilai seumur hidup pelanggan tanpa hubungan pelanggan yang berkualitas.

b) Variabel $C R M$ memiliki pengaruh positif terhadap CRQ, pengaruh tersebut terdukung dengan signifikan. Adanya pengaruh yang berkorelasi positif dan signifikan antara CRM terhadap CRQ sehingga Hipotesis 2 diterima. Hal ini menunjukkan proses manajemen hubungan pelanggan menggunakan alat-alat hubungan pelanggan bisa mempengaruhi hubungan pelanggan yang berkualitas dengan sangat signifikan.

c) Variabel $C R Q$ memiliki pengaruh positif terhadap CLV, pengaruh tersebut tersebut terdukung dengan signifikan. Adanya pengaruh yang berkorelasi positif dan signifikan antara CRQ terhadap CLV sehingga Hipotesis 3 diterima. Hal ini menunjukkan hubungan pelanggan yang berkualitas mampu mempengaruhi nilai seumur hidup pelanggan.

d) Variabel CRM memiliki pengaruh positif terhadap CLV dengan intervensi CRQ. CRM mempunyai pengaruh positif terhadap tingkat CLV dengan intervensi CRQ sehingga Hipotesis 4 diterima. Hal ini menunjukkan manajemen hubungan pelanggan akan 
mempengaruhi nilai seumur hidup pelanggan secara positif dan signifikan melalui hubungan pelanggan yang berkualitas.

\subsection{Saran}

Berdasarkan hasil dari penelitian maka terdapat saran-saran yang dapat disampaikan yaitu:

1. Bagi Rumah Zakat

Rumah Zakat harus terus menguatkan hubungan dengan pelanggannya dengan memperhatikan konsep CRM dan CRQ yang dapat menguatkan hubungan rumah zakat dengan pelanggannya. Hubungan yang kuat rumah zakat dengan pengan pelanggannya akan mengasilkan CLV atau nilai seumur hidup pelanggan yang tinggi.

Rumah Zakat akan terus bertahan dan semakin kuat sebagai lembaga amal zakat terbaik secara nasional dan suatu saat bisa menjadi LAZ internasional. Hal ini sangat mungkin terjadi karena dari dulu Rumah Zakat sudah menyalurkan bantuannya ke luar negeri di daerah umat muslim yang terkena musibah dan konflik.

Rumah Zakat harus meningkatkan Kampanye pembayaran Zakat yang lebih praktis dengan sistem online dan terkomputerisasi. Serta terus meningkatkan profesionalitas dan tetap Amanah dalam mengelola Zakat Umat Islam di Indonesia, serta semakin Peduli dengan keperluan Muzakki dan mustahiq zakat.

Kondisi persaingan usaha yang semakin global saat ini, mengharuskan lembaga amal zakat yang nirlaba harus bertransformasi untuk lebih amanah dan profesional, dan jangan hanya berada pakem tradisional. Sebenarnya LAZ juga bersaing dengan lembaga filantropi internasional lainnya. Profesionalitas mendukung kepercayaan umat islam untuk tetap menyalurkan dana sosialnya di lembaga zakat bukan di lembaga sosial lainnya.

2. Bagi Penelitian Selanjutnya.

Dalam rangka membangun teori dalam pelaksanaan CRM, CRQ dan CLV bagi peniliti, diharapkan dapat menambahkan variabel lain yang dapat meningkatkan tingkat CLV. Pada proposal sebelumnya Penulis ingin menggunakan kinerja salesman (KPI) sebagai variabel pendukung peningkatan CRM, CRQ, dan CLV karena salesman merupakan ujung tombak perusahaan untuk berhubungan dengan pelanggan.

Memperluas area sampel dan membagi katagori sampel berdasarkan domisili responden, agar dapat lebih menggambarkan hasil penelitian ini dengan kondisi Indonesia yang luas dan berpotensi cukup besar karena Indonesia termasuk memiliki umat Islam yang terbesar didunia.

\section{Daftar Pustaka}

“Agar Lebih Amanah Dalam Mengelola Dana Umat.” SW A.Co.Id (blog), 12 Mei 2011. https://swa.co.id/swa/trends/technology/agar-lebih-amanah-dalam-mengelola-dana-umat.

Assael, H. Consumer Behavior and Marketing Action. Boston, Mass: Kent Publishing Company, 1987.

Baird, Carolyn Heller, dan Gautam Parasnis. "From Social Media to Social Customer Relationship Management.” Strategy \& Leadership, 6 September 2011. https://doi.org/10.1108/10878571111161507.

Barnes, James G. Secrets of customer relationship management $=$ Rahasia manajemen bubungan pelanggan. Yogyakarta: Andi, 2003. 
Kotler, Philip, dan Kevin Lane Keller. Marketing Management, 2017.

Kotler, Philip, Kevin Lane Keller, Bernard Dubois, Delphine Manceau, Philip Kotler, dan Philip Kotler. Marketing management. Paris: Pearson Education France, 2009.

Peter Levers. "The Value of Trust.” Customer Attuned (blog), 19 Januari 2016. http://customerattuned.com/blog/the-value-of-trust/.

Satria, Dommy Dyotama. "Analisis Hubungan Antara Customer Relationship Management (Crm), Relationship Quality (Rq), Dan Customer Lifetime Value (Clv) (Studi Kasus: Hotel Grand Legi Mataram)," 2013.

Sugiyono. Metode penelitian pendidikan: (pendekatan kuantitatif, kualitatif dan R \& D). Bandung: Alfabeta, 2008. 